Latvia University of Agriculture

Latvijas Lauksaimniecības universitāte

Faculty of Food Technology

Pārtikas tehnologijas fakultāte

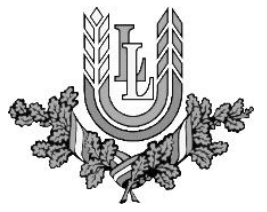

Mg. sc. sal. Līga Prieciṇa

\title{
EVALUATION OF BIOLOGICALLY ACTIVE COMPOUNDS IN FRESH AND DRIED VEGETABLES AND SPICES
}

\section{BIOLOGISKI AKTİVO SAVIENOJUMU IZVËRTËJUMS SVAIGOS UN KALTËTOS DĀRZENOS UN GAR $\check{S} A U G O S$}

\author{
SUMMARY
}

of the Doctoral Dissertation for the scientific degree of Dr. sc. ing.

Promocijas darba KOPSAVILKUMS

Dr. sc. ing. zinātniskā grāda iegūšanai 
Scientific supervisor /

Promocijas darba vadìtāja:

Prof., Dr.sc.ing. Daina Kārkliṇa

Official reviewers / Oficiālie recenzenti:

Dr. biol. Dace Tirzite (Researcher, Latvian Institute of Organic Synthesis / pētniece, Latvijas Organiskās sintēzes institūts)

Prof., Dr. habil. chem. Valdis Kampars (State Emeritus Scientist, Riga Technical university, Applied Chemistry Institute / Valsts emeritētais zinātnieks, Rīgas Tehniskā Universitāte, Lietišķās ķı̄mijas institūts)

Asoc.prof., Dr. sc.ing. Māra Dūma (Latvia University of Agriculture, Faculty of Food Technology, Department of Chemistry / Latvijas Lauksaimniecības universitāte, Pārtikas tehnoloğijas fakultāte, Ķ̄̇mijas katedra)

The research leading to these results has received partialy funding from the The State Research programme "Agricultural Resources for Sustainable Production of Qualitative and Healthy Foods in Latvia (AgroBioRes) (2014-2017)"; project No. 4 Sustainable use of local agricultural resources for qualitative and healthy food product development (FOOD) and the FENS Grant for Young Scientists from Eastern Europe for participation in $12^{\text {th }}$ European Nutrition Conference FENS 2015 in Berlin, 23-27 ${ }^{\text {th }}$ October, 2015.

Darba izstāde veikta ar Valsts pētījumu programmas Lauksaimniecības resursi igtspējīgai kvalitatīvas un veselīgas pārtikas ražošanai Latvijā (AgroBioRes) (2014-2017)”, projekts Nr.4 Vietējo lauksaimniecības produktu resursu ilgstspējīga izmantošana kvalitatīvu un veselīgu pārtikas produktu izstrādēe (Pārtika) dal̦ēju atbalstu un FENS grants Jaunajiem zinātniekiem no Austrumeiropas dalībai 12.Eiropas uztura konferencē FENS 2015 Berlīnē, 23-27.oktobrī, 2015.

The defence of the dissertation in an open session of the Promotion Board of Food Science of Latvia University of Agriculture will be held on $12^{\text {th }}$ June 2017 at 10 am in auditorium 216 at the Faculty of Food Technology, Latvia University of Agriculture, 22 Rigas Street, Jelgava.

Promocijas darba aizstāvēšana notiks LLU Pārtikas zinātnes nozares promocijas padomes atklātajā sēdē 2017. gada 12.jūnijā plkst.10. ${ }^{00}$ Pārtikas tehnologijas fakultātes 216.auditorijā Rìgas ielā 22, Jelgavā.

The dissertation is available at the Fundamental Library of the Latvia University of Agriculture, 2 Liela Street, Jelgava LV-3001, and on the internet http://llufb.llu.lv/promoc_darbi_en.html. References should be sent to Dr. sc. ing. I. Beitane, the Secretary of the Promotion Board of Food Science at the Faculty of Food Technology, Latvia University of Agriculture, 22 Rigas Street, Jelgava LV-3004, Latvia or e-mail: ilze.beitane@llu.lv.

Ar promocijas darbu un kopsavilkumu var iepazìties LLU Fundamentālajā bibliotēkā, Lielā ielā 2, Jelgavā LV-3001, un internetā (pieejams: http://llufb.llu.lv/promoc_darbi_en.html). Atsauksmes sūtìt Pārtikas zinātnes nozares promocijas padomes sekretārei, LLU Pārtikas tehnologijas faultātes asoc. prof. Dr.sc.ing. I. Beitānei (Rīgas iela 22, Jelgava LV-3004, e-pasts: ilze.beitane@llu.lv).

DOI: 10.22616/LLUthesis/2017.006 


\section{CONTENT}

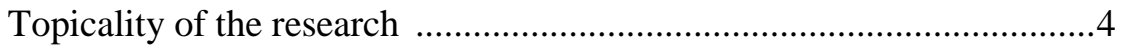

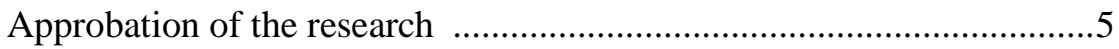

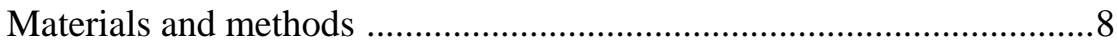

Results and discussion ................................................................. 12

1. Physical and chemical parameter differences in Apiaceae spices (dill, parsley, celery)...................................................12

2. Physical and chemical parameter differences in Apiaceae vegetables (celery root, carrot).............................................21

3. Physical and chemical parameter differences in Allium spices (leek, onion, garlic)...................................................28

4. Integrated evaluation of dried vegetables and spices .................37

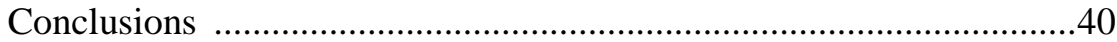

\section{SATURS}

Pètījuma aktualitāte ..................................................................... 43

Zinātniskā darba aprobācija .............................................................. 44

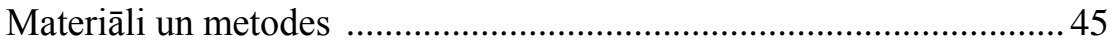

Rezultāti un diskusija ................................................................... 46

1. Fizikālo un ķīmisko parametru atšksirības Apiaceae garšaugos (dilles, pētersīḷi, selerijas)......................................4 46

2. Fizikālo un ķīmisko parametru atšķirības Apiaceae dārzeņos (seleriju saknes, burkāni).....................................................49

3. Fizikālo un ķīmisko parametru atšķirības Allium garšaugos (puravi, sīpoli, ķiploki)......................................................51

4. Kaltētu dārzeņu un garšaugu integrētais novērtējums ................53

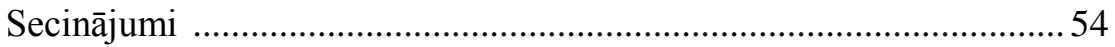




\section{TOPICALITY OF THE RESEARCH}

Vegetables and spices in the healthy diet occupy an important position. They contain vitamins, dietary fibres, sugars, organic acids, micro - and macroelements, and biologically active compounds. They have a relatively short shelf life, because of high moisture content (Patras et al., 20111; Hossain et al., 2011). Vegetables and spices are seasonal products. It is necessary to find the processing method for shelf life extension of fresh products in order to maintain their biological value. Many factors affect food components, especially phytochemicals, such as, growing conditions, temperature, light intensity, and water availability during growing and harvesting time (Alarcon-Flores et al., 2015). One of the most common shelf life maintenance method is drying. The use of high temperatures in foods affects adversely to the quality which can lead to the degradation of some nutritional compounds (Garcia-Parra et al., 2016). Drying temperatures should be within $45^{\circ} \mathrm{C}$ and $60^{\circ} \mathrm{C}$ in order to minimize the loss of volatile oils and discoloration in foods (Schweiggert et al., 2007). Drying at higher temperatures can result in degradation of phenolic compounds and affect antioxidant and free-radical scavenging capacities (Vashisth et al., 2011).

One of the most investigated drying methods among all studied drying technologies is convective type drying, when different drying temperatures are used for nutritional value preservation, however drying time varies from few hours even till few days depending on used temperature regime. In recent years microwave-vacuum (MV) drying process has gained recognition as another successful drying method. It is possible to ensure the drying temperature below $40 \pm 1^{\circ} \mathrm{C}$ during $\mathrm{MV}$ drying process furthermore processing time reduces significantly compared to convection-type drying at the same temperatures (up to a few hours) and direct oxygen effect is limited during drying. Therefore it is possible to make prognoses, that, drying vegetables and spices with MV drier, it is possible to maximally maintain their biologically active compounds, because minimised oxygen conditions limits oxidation processes in products.

In addition, according to EU regulation 2015/2283, MV drying process have been defined as novel process.

Therefore, investigations are required to evaluate the quality parameters and possibilities to maintain biological value of MV dried vegetables and spices compared to the same products obtained by convective-type dryer.

The hypothesis of the doctoral dissertation whether it is possible to maximally maintain biologically active compounds of vegetables and spices using microwave-vacuum drying.

The hypothesis of the doctoral dissertation was proven by the following statements:

1. Pre-treatment followed by microwave-vaccum drying improves biologically active compound content of Apiaceae spices(dills, parsleys, celeries); 
2. Microwave-vacuum drying improves biologically active compound content of Apiaceae vegetables (celery roots, carrots);

3. Microwave-vacuum drying improves biologically active compound content of Allium spices(leeks, onions, garlics);

4. Microwave-vacuum drying is the most appropriate drying method for obtaining dried vegetables and spices with increased biological value.

The research object of the doctoral dissertation: vegetables and spices grown in Latvia

The aim of the doctoral dissertation was to evaluate quality parameters and changes of biological value in dried vegetables and spices after steam blanching pre-treatment and drying in microwave-vacuum dryer compared to the same products obtained by convective-type dryer.

The following research objectives were set to reach the aim of the doctoral dissertation:

1. to investigate chemical and physical parameter changes of Apiaceae spices (dills, parsleys, celeries) after steam-blanching and drying;

2. to investigate chemical and physical parameter changes of Apiaceae vegetables (celery roots, carrots) after steam-blanching and drying;

3 . to investigate chemical and physical parameter changes of Allium spices (leeks, onions, garlics) after steam-blanching and drying;

4. to evaluate the most suitable drying method of obtained dried vegetables and spices with maximal biological value using the integrated method.

The novelty and scientific significance of the doctoral dissertation:

1. It has been investigated steam-blanching and two different drying techniques effect on biologically active compounds' content in vegetables and spices grown in Latvia.

2. It has been determined the drying method for each vegetable and spice for maintaining biological value at the highest level using integrated method.

The economic significance of the doctoral dissertation:

1. It is possible to use microwave-vacuum drying with steam blanching in processing of fresh vegetables and spices to obtaine the dried products with high content of biological compounds and to maintain their biological value.

\section{APPROBATION OF THE RESEARCH}

Research results have been summarised and published in 9 publications, including 3 publications indexed in the international citation database SCOPUS and Web of Science. 


\section{Publications / publikācijas - 9}

1. Liga Priecina, Daina Karklina (2015) Composition of major organic acids in vegetables and spices. In: CBU International Conference Proceedings 2015. Innovations in Science and Education, Vol.3, p.447-454. Prague, Czech Republic, March 25-27, 2015 (In Thomson Reuters, Ebscohost)

2. Liga Priecina, Daina Karklina (2014) Research of phenolics, flavonoids and carotenoids in vegetables and spices. In: Proceedings of IAC-EIaT 2014, ISBN 978-80-905791-1-8, p.205-214. Prague, Czech Republic, December 12-13, 2014 (CD Proceedings) (In Ebscohost)

3. Liga Priecina, Daina Karklina (2014) Natural antioxidant changes in fresh and dried spices and vegetables. International Journal of Biological, Agricultural, Biosystems, Life Science and Engineering Vol.8, No.5, p.442446.

4. Liga Priecina, Daina Karklina (2014) Determination of major sugars in fresh and dried spices and vegetables using high performance liquid chromatography. In: $9^{\text {th }}$ Baltic Conference on Food Science and Technology "Food for Consumers and Well Being" FOODBALT-2014. Conference proceedings, p.198-201. Jelgava, Latvia, May 8-9., 2014 (In Web of Science)

5. Liga Priecina, Daina Karklina (2013) Total polyphenols, flavonoids and antiradical activity of vegetables dried in conventive and microwavevacuum driers. In: Research for Rural Development 2013: Annual $19^{\text {th }}$ International Scientific Conference Proceedings, Jelgava, Latvia, May 1517, 2013, Latvia University of Agriculture, Jelgava: LLU. Vol.1, p.98-103. (In Scopus, Web of Science, Ebscohost)

6. Liga Priecina, Daina Karklina (2013) Total polyphenols, flavonoid content and antiradical activity of selected fresh vegetables and spices using acetone pre-treatment. International Proceeding of Chemical, Biological \& Environmental Engineering, Vol.59, p.92-96. Stockholm, Sweden, December 13-14, 2013 (CD Proceedings) (In Ebscohost)

7. Liga Priecina, Daina Karklina (2013) Total phenols, flavonoid content and antiradical activity of selected fresh and steamed vegetables and spices. In: Innovative and modern technology of food production: Proceedings of the International Scientific and Technical Conference, p. 139-143. Vladivostok, Russia, November 14-15, 2013.

8. Liga Priecina, Daina Karklina (2013) Total polyphenol, flavonoid and antiradical activity of celery, dill, parsley, onion and garlic dried in conventive and microwave-vacuum dryers. International Proceeding of Chemical, Biological \& Environmental Engineering, Vol.53, p.107-112. Moscow, Russia, July 27-28, 2013 (CD Proceeding) (In Ebscohost)

9. Liga Priecina, Daina Karklina (2013) Total polyphenols, flavonoid content and antiradical activity of dried parsley (Petroselinum crispum), celery (Apium graveolens) and dill (Anethum graveolens L.). Journal of International Scientific Publications: Agriculture \& Food, Vol.1, Part 1, 
p.279-286. Elenite Holliday Village, Sunny Beach, Bulgaria, June 2-6, 2013 (CD Proceeding)

The results of the research work have been presented at 15 international scientific and practical conferences, symposiums, summits and congresses in Bulgaria, the Czech Republic, Germany, Ireland, Latvia, Lithuania, Russia and Sweden

Presentations / prezentācijas - 16

1. Liga Priecina (2016) Phenolic and organic acid composition of steamblanched and dried parsley leaves. $5^{\text {th }}$ International Conference of Young Scientists "Young Scientists for Advance of Agriculture", Oral presentation / mutiskais referāts. Vilnius, Lithuania, November 10, 2016

2. Liga Priecina (2016) Phenolic and organic acid composition of steamblanched and dried pumpkins. Riga Technical University $57^{\text {th }}$ International Scientific Conference "Material science and applied chemistry" 2016, Oral presentation / mutiskais referāts. Riga, Latvia, October 21, 2016

3. Liga Priecina (2016) Influence of steam treatment and drying on carrots' phenolic composition, organic acids and carotenoid content. $2^{\text {nd }}$ International Conference Nutrition \& Health, Oral Presentation / mutiskais referäts. October 5-7, 2016

4. I. Gramatina, Sanita Sazonova, Z. Kruma, L. Skudra, L. Priecina (2016) Herbal extract application for extending shelf-life of pork meat. $2^{\text {nd }}$ International Conference Nutrition \& Health, Oral Presentation / mutiskais referäts. October 5-7, 2016

5. Liga Priecina (2016) Dehydration and thermal process effect on organic acids, phenolic compounds and total carotenoids in celery roots. IUFOST $201618^{\text {th }}$ World Congress on Food Science and Technology, Poster presentation / stenda referāts. Dublin, Ireland, August 21-25, 2016

6. Liga Priecina (2016) Organic acid, phenolic's and total carotenoid changes of thermally processed and dehydrated dills (Anethum graveolens L.). $6^{\text {th }}$ Global Summit on Medicinal and Aromatic Plants, Oral presentation / mutiskais referäts. Riga, Latvia, May 23-26, 2016

7. Liga Priecina (2015) Phenolic compounds in fresh and processed vegetables and spices. The $12^{\text {th }}$ European Nutrition Conference FENS 2015, Poster presentation / stenda referäts. Berlin, Germany, October 20-23, 2015

8. Liga Priecina (2015) Composition of major organic acids in vegetables and spices. Central Bohemia University (CBU) International Conference Innovations in Science and Education, Oral presentation / mutiskais referāts. Prague, Czech Republic, March 25-27, 2015

9. Liga Priecina (2014) Research of phenolics, flavonoids and carotenoids in vegetables and spices, International Academic Conference on Engineering, Internet and Technology (IAC-EIaT 2014) in Prague 2014, Oral 
presentation / mutiskais referāts. Prague, Czech Republic, December 12-13, 2014

10. Priecina L. (2014) Sugars, total carotenoids and phenols in microwavevacuum drier processed vegetables and spices. $14^{\text {th }}$ International Nutrition \& Diagnostics Conference (INDC 2014), Oral presentation / mutiskais referāts. Prague, Czech Republic, September 2-5, 2014

11. Liga Priecina (2014) Natural antioxidant changes in fresh and dried spices and vegetables. International Science Conference on Food Engineering and Biotechnology, Oral presentation / mutiskais referāts. Berlin, Germany, May 22-23, 2014

12. Liga Priecina (2014) Determination of major sugars in fresh and dried spices and vegetables using high performance liquid chromatography. $9^{\text {th }}$ Baltic Conference on Food Science and Technology "Food for Consumers and Well-Being" FOODBALT-2014. Poster presentation / stenda referāts, Jelgava, Latvia, May 8-9, 2014

13. Liga Priecina (2013) Total polyphenols, flavonoid content and antiradical activity of selected fresh vegetables and spices using acetone pre-treatment. $2^{\text {nd }}$ International Conference on Environment, Chemistry and Biology ICECB 2013. Oral presentation / mutiskais referāts, Stockholm, Sweden, December 13-14, 2013

14. Liga Priecina (2013) Total polyphenol, flavonoid content and antiradical activity of dried parsley (Petroselinum crispum), celery (Apium graveolens) and dill (Anethum graveolens L.). Poster presentation / stenda referāts, Elenite Holliday Village, Sunny Beach, Bulgaria, June 3-6, 2013

15. Liga Priecina (2013) Total polyphenols, flavonoids and antiradical activity of vegetables dried in conventive and microwave-vacuum driers. Annual $19^{\text {th }}$ International Scientific Conference, Oral presentation / mutiskais referāts. Jelgava, Latvia, May 15-17, 2013

16. L. Priecina (2012) Spice plants and vegetables- sources of natural antioxidants. International Conference "Nutrition and Health", Poster presentation / stenda referāts. Riga, Latvia, September 4-6, 2012.

\section{MATERIALS AND METHODS}

\section{Time and place of the research}

Experiments were carried out during the period from 2012 to 2015. Product development and analysis were performed at Latvia University of Agriculture at Faculty of Food Technology laboratories. 


\section{Materials used in the research}

In the research 8 vegetables and spices were analysed and grouped based on the plant families (Table 1) and processed samples abbreviated (Table 2).

Table 1 / 1. tabula

Analysed sample grouping / Analizēto paraugu grupējums

\begin{tabular}{|l|l|}
\hline Family / Dzimta & Vegetables, spices/ Dārzeni, garšaugi \\
\hline \multirow{3}{*}{ Apiaceae spices / garšaugi } & Dills / Dilles \\
\cline { 2 - 2 } & Parsleys / Pētersīl i \\
\cline { 2 - 2 } & Celeries / Selerijas \\
\hline \multirow{2}{*}{ Apiaceae vegetables / dārzeņi } & Celery roots / Seleriju saknes \\
\cline { 2 - 2 } & Carrots / Burkāni \\
\hline \multirow{3}{*}{ Allium spices / garšaugi } & Leeks / Puravi \\
\cline { 2 - 2 } & Onions / Sīpoli \\
\cline { 2 - 2 } & Garlics / Kiploki \\
\hline
\end{tabular}

Table 2 / 2. tabula

Processing abbrevations for analysed vegetables and spices / Analizēto dārzeņu un garšaugu apstrādes veidu apzīmējumi

\begin{tabular}{|c|c|}
\hline Processing type / Apstrādes veids & $\begin{array}{c}\text { Abbrevation/ } \\
\text { Apzīmējums }\end{array}$ \\
\hline Fresh / Svaigi & $\mathrm{F}$ \\
\hline Convective dried / Kaltêti konvekcijas tipa kaltē & $\mathrm{CV}$ \\
\hline $\begin{array}{l}\text { Microwave-vacuum (MV) dried / } \\
\text { Mikroviļnu-vakuuma (MV) kaltē kaltêti }\end{array}$ & MV \\
\hline Steam-blanched for $1.5 \mathrm{~min} /$ Apstrādāti ar tvaiku $1.5 \mathrm{~min}$ & SB1 \\
\hline Steam-blanched for $3.0 \mathrm{~min} /$ Apstrādāti ar tvaiku $3.0 \mathrm{~min}$ & SB2 \\
\hline $\begin{array}{l}\text { Steam-blanched for } 1.5 \mathrm{~min} \text { and MV dried / } \\
\text { Apstrādāti ar tvaiku } 1.5 \text { min un kaltêti MV kaltē }\end{array}$ & SB1_MV \\
\hline $\begin{array}{l}\text { Steam-blanched for } 3.0 \mathrm{~min} \text { and MV dried / } \\
\text { Apstrādāti ar tvaiku } 3.0 \text { min un kaltēti MV kaltēe }\end{array}$ & SB2_MV \\
\hline
\end{tabular}

\section{Research structure}

The study was conducted in four stages (Fig. 1) and the technological scheme of the research is summarised in Fig. 2.

\section{Stage I - Fresh vegetables and spices}

In research eight vegetables and spices (dill, celery, parsley, leek, onion, garlic, carrot, and celery root) were used, grown in Zemgale region, Latvia and gathered during their maturity stage (from September till the beginning of October) and straight after gathering physical and chemical parameters were analysed.

Stage II - Conventional and microwave-vacuum dried vegetables and spices

The previously mentioned vegetables and spices were prepared for the drying process celery roots, carrots, leeks, onions and garlics were cut in 3 to 
$3.5 \mathrm{~mm}$ slices, while for drying dills, parsleys and celeries leaves/ green parts without stalks were used. For each drying 3 to $3.5 \mathrm{~kg}$ of the sample was prepared. After drying physical and chemical parameters were analysed.

\begin{tabular}{|c|c|}
\hline STAGE I / POSMS & $\begin{array}{l}\text { FRESH VEGETABLES AND SPICES / } \\
\text { SVAIGI DĀRZENI UN GARŠAUGI } \\
\text { Physical andchemical parameters / Fizikāli-kimiskie parametri }\end{array}$ \\
\hline STAGE II / POSMS & $\begin{array}{l}\text { CONVENTIONAL AND MICROWAVE-VACUUM } \\
\text { DRIED VEGETABLES AND SPICES / } \\
\text { KONVENCIONALI UN MIKROVILNUU-VAKUUMA KALTE } \\
\text { KALTETTI DARRZENI UN GARŠAUGI } \\
\text { Physical and chemical parameters / Fizikāli-ķimiskie parametri }\end{array}$ \\
\hline STAGE III / POSMS & 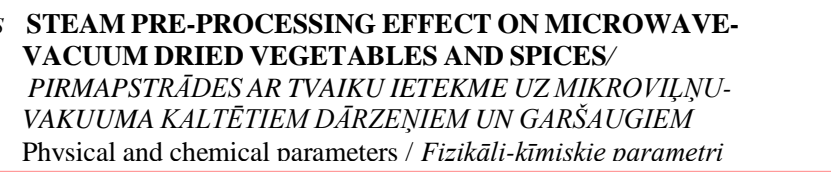 \\
\hline STAGE IV/POSMS & $\begin{array}{l}\text { INTEGRATED EVALUATION OF DRIED VEGETABLES } \\
\text { AND SPICES } \\
K A L T E T U D \bar{A} R Z E N U U N G A R S ̌ A U G U \text { INTEGRE TAIS NOVE } R T \bar{E} J U M S\end{array}$ \\
\hline
\end{tabular}

Fig.1. Structure of the research / 1. att. Pētijuma struktūra

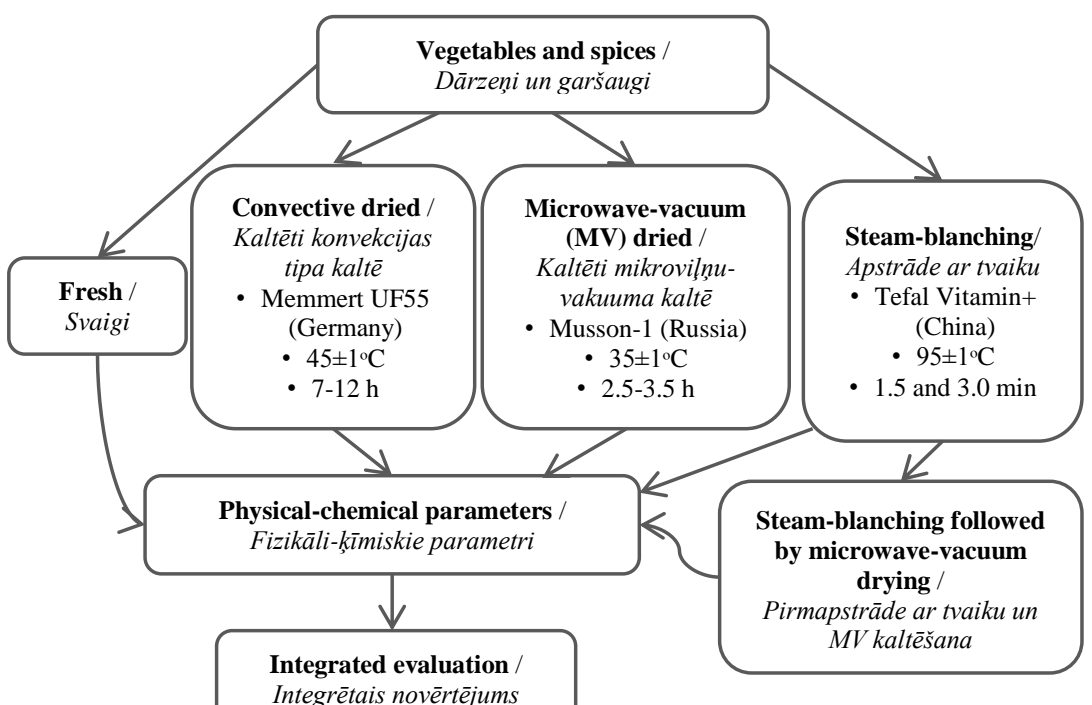

Fig. 2. Technological sheme of the research

2. att. Pētījuma tehnoloğiskā shēma 


\section{Stage III - Steam pre-processing effect on MV dried vegetables and spices}

Steam-blanching was used to determine the possibility of improving the physical and chemical parameters of dried vegetables and spices in microwavevacuum drying. Samples for steam-blanching were prepared in the same way as for drying and steam-blanched for 1.5 and $3.0 \mathrm{~min}$ in the chamber type steam cooker (Tefal Vitamin+, China) covered with lid and steamed over boiling water $\left(95 \pm 1^{\circ} \mathrm{C}\right)$ in a single layer. After steam-blanching the samples were put in a plastic bag and cooled in the ice water bath (for faster cooling process). The steam-blanched samples were used for physical and chemical parameter analysis and for MV drying. For MV dried samples with steam-blanching preprocessing physical and chemical parameters were analysed.

\section{Stage IV - Integrated evaluation of dried vegetables and spices}

Integrated evaluation was used for dried vegetables and spices to evaluate the most suitable drying technique to maintain the biological value.

\section{Methods used in the research}

Methods used to determine physical and chemical parameters are summarized in Table 3.

Table 3 / 3. tabula

\section{Standards and analytical methods used for analysis of vegetables and spices /}

Dārzeņu un garšaugu paraugu analizēšanai izmantotie standarti un metodes

\begin{tabular}{|c|c|c|}
\hline $\begin{array}{l}\text { No/ } \\
\text { Nr. }\end{array}$ & 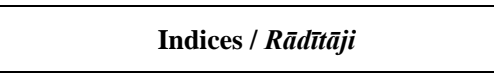 & Standarts, methods / Standarti, metodes \\
\hline \multicolumn{3}{|c|}{ Physical parameters / Fizikälie parametri } \\
\hline 1. & Moisture / Mitrums & $\begin{array}{l}\text { AOAC } 1995 \text { (Mazzeo et al., 2011; Sulaiman, } \\
\text { 2011) }\end{array}$ \\
\hline 2. & Colour / Krāsa & CIE L"a* ${ }^{*}{ }^{*}$ (Zhu et al., 2014) \\
\hline \multicolumn{3}{|c|}{ Chemical parameters / Kümiskie parametri } \\
\hline 3. & Individual sugars / Cukuri & $\begin{array}{l}\text { Dimins et al., 2008; Saldivar et al., 2010; } \\
\text { Beitane et al., 2013 }\end{array}$ \\
\hline 4. & Total carotenoids / Kopējie karotinoìdi & ГОСТ Р 54058-2010 (2011) \\
\hline 5. & Organic acids / Organiskās skābes & Sherer et al., 2012; Bae et al., 2014 \\
\hline 6. & Total phenolics / Kopējie fenoli & Bozin et al., 2007 \\
\hline 7. & Total phenolic acids / Kopējās fenolskābes & Gawlic-Dziki, 2012 \\
\hline 8. & Total flavonoids / Kopējie flavonoīdi & Olivera et al., 2008 \\
\hline 9. & Total flavonols / Kopējie flavonoli & Loziene et al., 2007 \\
\hline 10. & $\begin{array}{l}\text { Total flavan-3-ols (proanthocyanidins) / } \\
\text { Kopējie flavan-3-oli (proantocianidīni) }\end{array}$ & Zam et al., 2012 \\
\hline 11. & $\begin{array}{l}\text { Individual phenolics / } \\
\text { Individuālie fenolu savienojumi }\end{array}$ & $\begin{array}{l}\text { Chen et al., 2001; Wang \& Zhao, 2011; } \\
\text { Gokturk Baydar \& Baydar, 2013; Lazarova } \\
\text { et al., } 2014\end{array}$ \\
\hline 12. & $\begin{array}{l}\text { Antiradical activity / } \\
\text { Antiradikālā aktivitāte (DPPH; ABTS) }\end{array}$ & Affify et al., 2012; Erkan et al., 2011 \\
\hline
\end{tabular}

Used organic acids and phenolic compounds for quantification with high performance liquid chromatography are given in Table 4. 
Table 4 / 4.tabula

Analysed organic acids and phenolic compounds / Analizētās organiskās skäbes un fenolu savienojumi

\begin{tabular}{|c|c|c|c|}
\hline \multicolumn{4}{|c|}{ Compounds / Savienojumi } \\
\hline $\begin{array}{l}\text { Oxalic acid / } \\
\text { Skābenskābe }\end{array}$ & $\begin{array}{l}\text { Succinic acid / } \\
\text { Dzintarskābe }\end{array}$ & $\begin{array}{l}\text { 4-hydroxybenzoic } \\
\text { acid / 4- } \\
\text { hidroksibenzoskābe }\end{array}$ & $\begin{array}{l}\text { Sinapic acid / } \\
\text { Sinapinskābe }\end{array}$ \\
\hline $\begin{array}{c}\text { Tartaric acid / } \\
\text { Vinskkābe }\end{array}$ & $\begin{array}{l}\text { Salicylic acid / } \\
\text { Salicilskābe }\end{array}$ & $\begin{array}{l}\text { Vanillic acid / } \\
\text { Vanilīnskābe }\end{array}$ & $\begin{array}{l}\mathrm{t} \text {-ferulic acid / } \\
t \text {-ferulskābe }\end{array}$ \\
\hline $\begin{array}{l}\text { Quinic acid / } \\
\text { Hinīnskābe }\end{array}$ & $\begin{array}{l}\text { Benzoic acid / } \\
\text { Benzoskābe }\end{array}$ & $\begin{array}{l}\text { Homovanillic acid / } \\
\text { Homovanilīnskābe }\end{array}$ & $\begin{array}{l}\text { 2-hydroxycinnamic acid/ } \\
\text { 2-hidroksikanēlskāabe }\end{array}$ \\
\hline $\begin{array}{l}\text { Malic acid / } \\
\bar{A} \text { bolskābe }\end{array}$ & $\begin{array}{l}\text { Gallic acid / } \\
\text { Galluskābe }\end{array}$ & $\begin{array}{c}\text { Caffeic acid / } \\
\text { Kafijskābe }\end{array}$ & $\begin{array}{l}\text { Rutin / } \\
\text { Rutīns } \\
\end{array}$ \\
\hline $\begin{array}{l}\text { Malonic acid / } \\
\text { Malonskābe }\end{array}$ & $\begin{array}{l}\text { 3.4-dihydroxybenzoic acid / } \\
\text { 3.4-dihidroksibenzoskābe }\end{array}$ & $\begin{array}{l}\text { (-) epicatechin / } \\
\text { (-)-epikatehīns }\end{array}$ & $\begin{array}{c}\text { t(3)-hydroxycinnamic acid/ } \\
\text { t(3)-hidroksikanēlskābe }\end{array}$ \\
\hline $\begin{array}{l}\text { Ascorbic acid / } \\
\text { Askorbinskābe }\end{array}$ & $\begin{array}{l}\text { 3.5-dihydroxybenzoic acid/ } \\
\text { 3.5-dihidroksibenzoskābe }\end{array}$ & $\begin{array}{l}\text { Syringic acid / } \\
\text { Cerinskāabe }\end{array}$ & $\begin{array}{l}\text { Quercetin / } \\
\text { Kvercetīns } \\
\end{array}$ \\
\hline $\begin{array}{l}\text { Citric acid / } \\
\text { Citronskābe }\end{array}$ & $\begin{array}{c}\text { (+)-catechin / } \\
(+) \text {-katehīns }\end{array}$ & $\begin{array}{l}\text { Vanillin / } \\
\text { Vanilins } \\
\end{array}$ & $\begin{array}{l}\text { Luteolin / } \\
\text { Luteolinns } \\
\end{array}$ \\
\hline $\begin{array}{l}\text { Fumaric acid / } \\
\text { Fumārskābe }\end{array}$ & $\begin{array}{l}\text { Chlorogenic acid / } \\
\text { Hlorogēnskābe }\end{array}$ & $\begin{array}{l}\text { p-coumaric acid / } \\
\text { p-kumarinskābe }\end{array}$ & $\begin{array}{l}\text { Kaempferol / } \\
\text { Kaempferols }\end{array}$ \\
\hline
\end{tabular}

\section{Data analysis}

The obtained data processing was performed using statistical software 'Microsoft Office Excel v10.0' and 'XLSTAT 2016'. The results were given as mean value \pm standard deviation. Student's t-test, single factor and multifactor analysis of variance (ANOVA) was used to compare the means. Differences were considered significant at $p \leq 0.05$. Pearson's correlation coefficient was calculated to determine the association between the results. Principal component analysis (PCA) was used to evaluate each analysed sample processing effect on organic acid and phenolics contribution (the relationship between the processing of the sample and the type of organic acids and phenolic compound distribution). Integrated evaluation was applied for dried vegetables and spices and performed using physical and chemical parameters.

\section{RESULTS AND DISCUSSION}

\section{Physical and chemical parametrs in Apiaceae spices (dills, parsleys and celeries)}

Moisture content in dills were $84.64 \pm 0.85 \%$, in celeries- $80.62 \pm 0.81 \%$ and in parsleys- $78.98 \pm 0.79 \%$ and steam-blanching minimally affected moisture content; with convectional drying content and MV drying process initial content was decreased till less than $10 \%$.

Colour differences were calculated for steam-blanched and dried dills, parsleys and celeries for comparison with fresh samples. In all previously mentioned samples steam blanching did not gave visually visible changes 
compared with fresh ones $(\Delta \mathrm{E}<10)$, while with drying processes were observed significant changes.

Carotenoids in spices and vegetables are one of major antioxidants. In dills, parsleys and celeries their total amount varies from $278.67 \pm 16.64$ to $469.00 \pm 13.83 \mathrm{mg} \beta-\mathrm{CE} 100 \mathrm{~g}^{-1} \mathrm{DW}$ and processing affects carotenoid amount differently (Fig.3.).
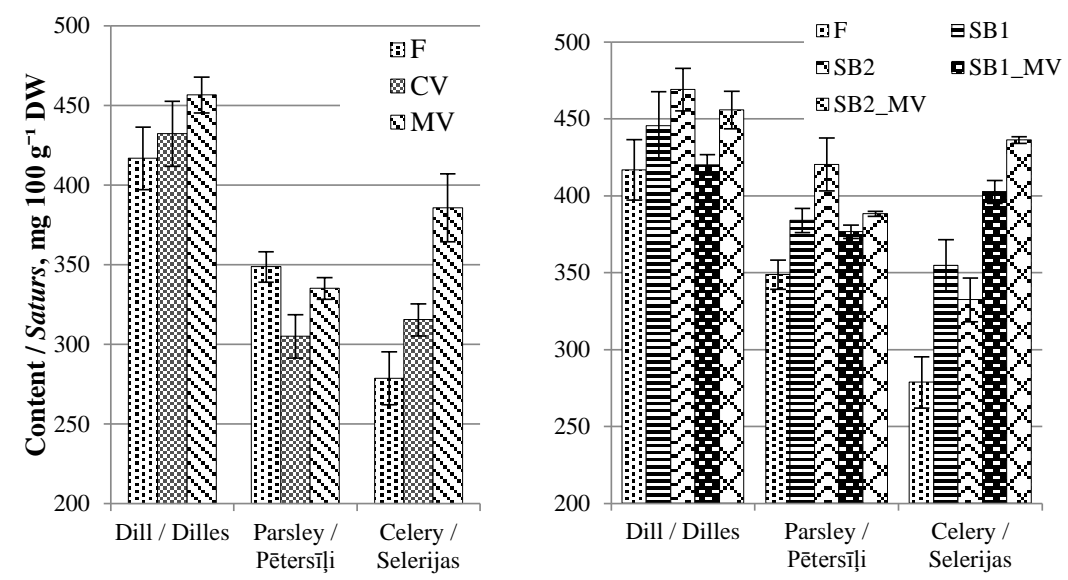

Fig. 3 Total carotenoids in dills, parsleys and celeries 3.att. Kopējo karotinoūdu saturs dillēs, pātersīḷos un selerijās

The highest carotenoid content was determined in dills, the lowest content in celeries. In dills carotenoid content was high and steam-blanching for 1.5 min minimally affected total amount, while with 3.0 min processing content significantly increased. In parsley's carotenoid content with steam-blanching process slightly increased. In celeries carotenoid content with thermal and drying processing increased in all cases- with steam-blanching amount increased more than with convective drying, and after MV processing total carotenoids increased significantly compared with fresh celeries.

In dills organic acids found in fresh and dried samples were oxalic, ascorbic, citric, succinic, salicylic and benzoic acids at various concentrations (Table 5).

Oxalic acid with steam-blanching decreased in dills, but with drying process initial amount increased. Quinic acid in dills was determined in high amount and with short time steam-blanching process content significantly decreased.

Malic acid in fresh dills was determined at high concentrations and steamblanching and drying process degraded initial amount, while malonic acid was not detected in fresh samples and thermal and drying process helped to increase particular acid. In dills citric acid amount significantly degraded using steam processing, but drying process initial content increased. 
Fumaric acid in dills degraded with steam-blanching process and in dried samples was detected in low concentration.

Table 5 / 5. tabula

Organic acid composition of fresh, dried and steam-blanched dills / Organisko skābju sastāvs svaigās, kaltētās un tvaiku apstrādātās dillēs

\begin{tabular}{|l|c|c|c|c|c|c|c|}
\hline Acids & F & CV & MV & SB1 & SB2 & SB1_MV & SB2_MV \\
\hline Oxalic & 349.71 & 526.33 & 444.98 & 245.55 & 280.36 & 382.65 & 398.76 \\
\hline Tartaric & n.d. & n.d. & n.d. & 674.89 & 141.02 & n.d. & n.d. \\
\hline Quinic & 7398.18 & n.d. & n.d. & 960.93 & n.d. & n.d. & n.d. \\
\hline Malic & 5312.60 & n.d. & n.d. & n.d & n.d. & n.d. & n.d. \\
\hline Malonic & n.d. & 1558.95 & 1732.09 & 2338.74 & 3167.41 & 2080.95 & 2534.33 \\
\hline Ascorbic & 320.29 & 150.19 & 185.84 & 258.14 & 225.68 & 141.03 & 130.87 \\
\hline Citric & 1941.73 & 4032.24 & 5614.89 & 736.92 & 775.13 & 559.61 & 445.00 \\
\hline Fumaric & 273.23 & 1.57 & 0.14 & n.d. & n.d. & 4.56 & 6.64 \\
\hline Succinic & 32.37 & 2600.41 & 1773.56 & 21.25 & 25.72 & 75.85 & 695.82 \\
\hline Salicylic & 6.11 & 16.26 & 4.61 & 7.38 & 12.11 & 4.03 & 2.00 \\
\hline Benzoic & 1.86 & 24.82 & 7.17 & 7.54 & 2.89 & 64.17 & 2.33 \\
\hline Total & 15636.08 & 8910.77 & 9763.29 & 5251.35 & 4630.32 & 3312.86 & 4215.76 \\
\hline
\end{tabular}

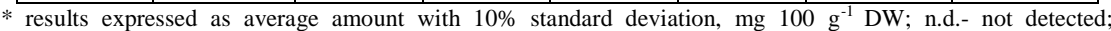
compounds gathered in Table 4/ rezultāti izteikti kā vidējais rezultāts ar $10 \%$ standartnovirzi; n.d-nav konstatēti; savienojumi apkopoti 4.tabulā

Succinic acid in fresh dills was observed in lower concentrations and thermal process minimally degraded acid. With drying process succinic acid in dills significantly increased. Salicylic acid in dills started to increase with steam-blanching and highest increase was observed in convective dried dills, while with MV drier processing initial salicylic acid degraded and preprocessing degraded content more. Increase in benzoic and salicylic acid may be explained by chemical processes during process. Plant benzoic acids can be modified or converted to another hydroxyl benzoic acid forms through hydroxylation (Widhalm \& Dudareva, 2015).

In parsleys founded in fresh and dried samples were oxalic, quinic, malonic, ascorbic, citric, succinic and salicylic acids in various concentrations and had tendency to change (Table 6).

In parsley's oxalic acid significantly degraded after steam blanching, while with convective drying content increase. Obtained results can be compared to Han et al. (2016) research. According to researchers, oxalic acid is thermo stable in temperatures lower than $80^{\circ} \mathrm{C}$ and with higher temperatures compound starts to degrade leading to decreased initial amount.

Quinic acid decreased in parsleys with thermal process, while with convective and MV drier acid concentration increased. With convective drying citric acid in parsleys increased, but with MV drying decreased. Succinic acid in parsleys significantly decreased with thermal process and positive effect was observed in dried parsleys. 
Table 6 / 6. tabula

Organic acid composition in fresh, dried and steam-blanched parsleys / Organisko skābju sastāvs svaigos, kaltētos un ar tvaiku apsträdātos pētersīḷos

\begin{tabular}{|l|c|c|c|c|c|c|c|}
\hline \multicolumn{1}{|c|}{ Acids } & F & CV & MV & SB1 & SB2 & SB1_MV & SB2_MV \\
\hline Oxalic & 479.64 & 1550.77 & 296.50 & 182.07 & 203.30 & 323.20 & 115.60 \\
\hline Tartaric & 733.55 & n.d. & 1062.34 & 293.34 & 775.45 & 502.57 & n.d. \\
\hline Quinic & 1168.87 & 2581.04 & 2197.23 & 738.46 & 179.69 & 421.90 & 1602.69 \\
\hline Malic & n.d. & n.d. & n.d. & 79.88 & n.d. & n.d. & 616.13 \\
\hline Malonic & 1748.02 & 4317.67 & 3047.78 & 58.93 & 126.89 & 3409.24 & 3566.74 \\
\hline Ascorbic & 285.66 & 207.05 & 235.80 & 247.57 & 215.18 & 196.44 & 163.97 \\
\hline Citric & 1940.34 & 2640.39 & 1038.92 & 407.43 & 850.71 & 2017.53 & 297.00 \\
\hline Fumaric & n.d. & 0.43 & 0.52 & n.d. & n.d. & 4.85 & 0.93 \\
\hline Succinic & 273.05 & 598.06 & 969.41 & 16.04 & 51.32 & 12.21 & 189.53 \\
\hline Salicylic & 72.85 & 59.75 & 74.55 & 29.26 & 37.40 & 47.46 & 5.48 \\
\hline Benzoic & 0.21 & 0.83 & n.d. & 2.37 & 2.38 & 3.03 & 0.14 \\
\hline Total & 6702.20 & 11956.00 & 8923.04 & 2055.35 & 2442.32 & 6938.41 & 6558.20 \\
\hline
\end{tabular}

* results expressed as average amount with $10 \%$ standard deviation, $\mathrm{mg} 100 \mathrm{~g}^{-1}$ DW; n.d.- not detected; compounds gathered in Table 4/ rezultāti izteikti kā vidējais rezultāts ar $10 \%$ standartnovirzi; $n$.d-nav konstatēti; savienojumi apkopoti $4 . t a b u l a \bar{~}$

Total organic acid content in parsleys degraded using steam-blanching, while with convective drying total amount increased significantly due to increase in oxalic, quinic, malonic and citric acids.

In celeries main organic acids were oxalic, ascorbic, citric, and salicylic and benzoic acids in various concentrations and initial content changed (Table 7).

Table 7 / 7.tabula

\section{Organic acid composition in fresh, dried and steam-blanched celeries /} Organisko skābju sastāvs svaigās, kaltētās un ar tvaiku apstrādātās selerijās

\begin{tabular}{|l|c|c|c|c|c|c|c|}
\hline \multicolumn{1}{|c|}{ Acids } & F & CV & MV & SB1 & SB2 & SB1_MV & SB2_MV \\
\hline Oxalic & 244.37 & 244.65 & 81.34 & 152.00 & 152.91 & 823.49 & 176.91 \\
\hline Tartaric & n.d. & n.d. & n.d. & n.d. & 231.62 & 530.51 & n.d. \\
\hline Quinic & 714,24 & n.d. & n.d. & 781.70 & 775.74 & n.d. & n.d. \\
\hline Malic & n.d. & n.d. & n.d. & 3930.85 & 1679.30 & 9545.30 & n.d. \\
\hline Malonic & 4924.47 & 6044.48 & 7172.09 & n.d. & n.d. & n.d. & 5522.16 \\
\hline Ascorbic & 221.24 & 105.99 & 170.78 & 125.88 & 98.89 & 122.70 & 107.83 \\
\hline Citric & 4011.61 & 945.93 & 749.01 & 3632.83 & 958.46 & 1622.20 & 101.06 \\
\hline Fumaric & n.d. & 0.06 & 0.06 & n.d. & n.d. & 12.88 & 1.14 \\
\hline Succinic & 267.60 & n.d. & n.d. & 31.23 & 17.92 & 74.53 & n.d. \\
\hline Salicylic & 21.62 & 36.01 & 21.00 & 34.32 & 16.64 & 4.17 & 0.39 \\
\hline Benzoic & 4.73 & 0.92 & 4.31 & 3.16 & 1.78 & 3.05 & 0.31 \\
\hline Total & 10409.88 & 7378.04 & 8198.60 & 8691.98 & 3933.27 & 12738.83 & 5909.80 \\
\hline
\end{tabular}

In celeries oxalic acid degraded with steam-blanching and MV drying, and steam-blanching followed by MV drying increased initial amount compared to MV dried celeries acid content. The temperature, and the pressure and high 
acoustic amplitudes in combination helped to degrade oxalic acid more. The best degradation was observed when power was increased (Dukkanci \& Gunduz, 2006). Quinic acid in celeries degraded and degradation rate was similar both in steam blanched and convective dried samples.

Citric acid in celeries started to degrade with short steam-blanching process and with longer steam-blanching process was observed significant decrease and that was at the same level as in convective dried celeries. Benzoic acid in celeries was detected in lower concentrations than other organic acids and thermal and convective drying processes degraded acid more than MV drying.

Malic acid is a compound, which undergoes a series of distinct decarboxylation steps during its degradation, and photodegradation has been seriously studied. During possible photodegradation process of malic acid malonic acid may form and other final degradation products (Irawaty et al., 2011)

Phenolic compounds (phenolics, flavonoids and phenolic acids) in spices were found in various concentrations and drying and steam-blanching processing affected total amount differently. After drying initial phenolic, flavonoid and phenolic acid content significantly increased and the highest phenolic content was determined in dills. Steam-blanching process helped to improve total phenolic content in MV dried Apiaceae spices and 3.0 min steamblanching followed by MV drying increased initial content more in dills and parsleys (Fig.4).

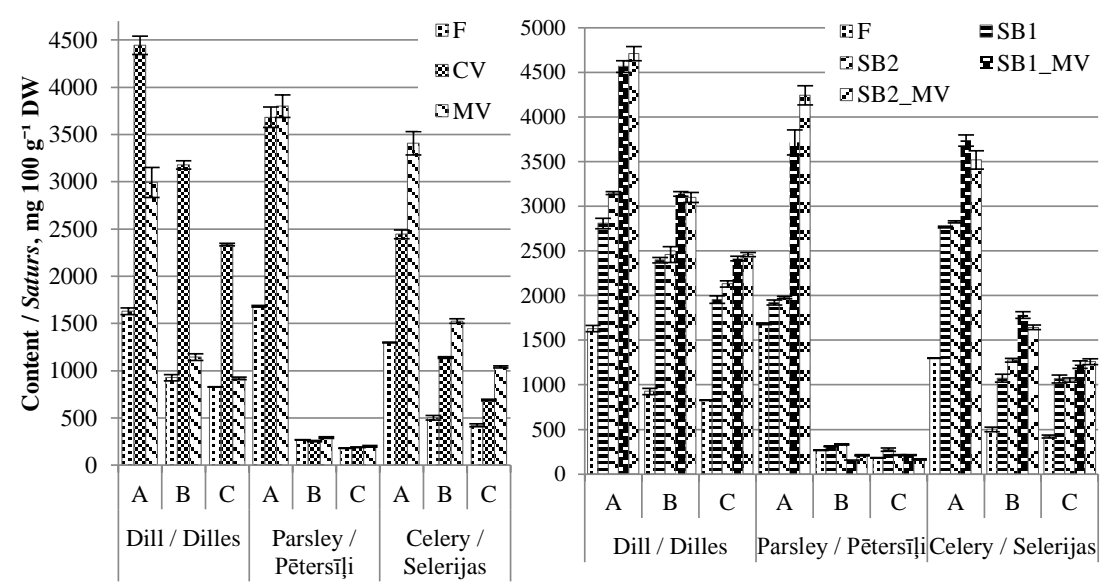

Fig.4. Total phenolic (A), flavonoid (B) and phenolic acid (C) content in steam-blanched and MV drier processed Apiaceae spices /

4.att. Kopējais fenolu (A), flavonō̄du (B) un fenolskābju (C) saturs tvaicētos un MV kaltē apstrādātos Apiaceae garšaugos 
Some reducing components, such as ascorbic acid, can be oxidised by the Folin-Ciocalteu reagent of the total phenolic assay, yielding on increased total amount using this method (Zhang \& Hamauzu, 2004).

In dills, parsleys and celeries flavonoid content increased with steamblanching and convective drying, and steam-blanching followed by MV drying had significant higher flavonoid content than MV dried spices. Similar tendency was observed in total phenolic acid content, where significant higher concentrations was detected in steam-blanched and in convective dried spices, and in samples pre-processed followed by MV drying.

Simple phenolics are widely distributed especially in root vegetables, while glycosides of flavones and flavonols are mainly found in leaf vegetables, but aglycones of flavones and flavonols in parsleys, celeries, broccoli and herbs (Sakakibara et al., 2003). Phenolic composition of fresh and processed plants varies depending on various conditions, including temperatures and oxygen availability during processing.

Individual phenolic composition of dills and concentrations changes with steam-blanching and drying processes. The highest changes were observed in 4-hydroxybenzoic acid, 3.5-dihydroxybenzoic acid, sinapic acid, chlorogenic acid and rutin contents.

The initial matrix of 7 processed dill samples and 32 compounds (phenolic compounds and organic acids) was analysed using principal component analysis (PCA). The PCA of processed dills resulted in a two component model that explained by $62.00 \%$ variance. The first component accounted by $39.96 \%$, the second by $22.04 \%$ (Fig.5). The correlation plots showed clustering of the processed dills in a 3 main groups- fresh and steam-blanched (for 1.5 and 3.0 min), convective dried and MV dryer processed dills.

For fresh and steam-blanched dills phenolic compounds and organic acids in highest amounts were rutin, (-)-epicatechin, malic, fumaric, quinic, ascorbic, t-ferulic, homovanillic, 3.4-dihydroxybenzoic, tartaric, 2-hydroxycinnamic and 4-hydroxybenzoic acids. Using convective drying the highest content was observed in vanillin, quercetin, kaempferol, salicylic, citric, syringic, caffeic, 3hydroxycinnamic, p-coumaric, oxalic, succinic and sinapic acids. The highest concentrations using MV drying were observed for luteolin, (+)-catechin, gallic, chlorogenic, benzoic, vanillic and 3.5-dihydroxybenzoic acids. 


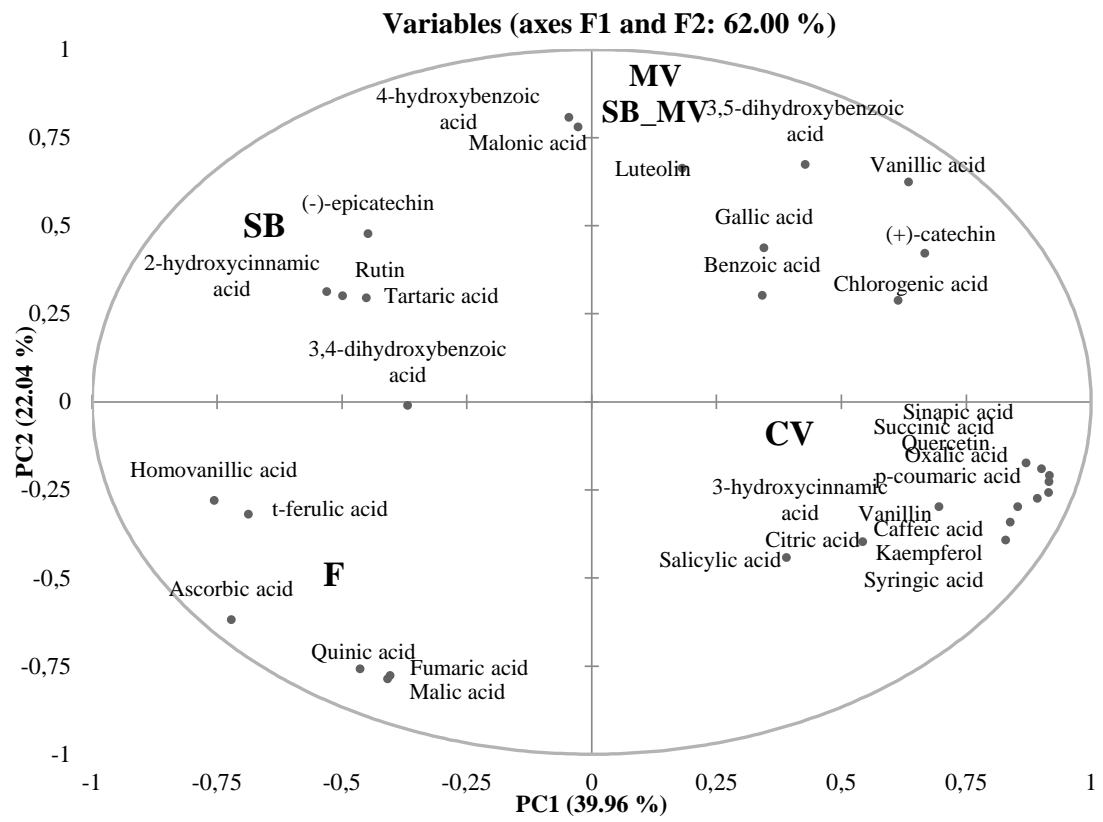

Fig.5 Principal Component scores of processed dills and distribution of phenolic and organic acids/

5.att. Galveno komponentu analīzes vērtības apstrādātām dillēm un fenolu un organisko skābju izkliede

Phenolic compounds of processed parsleys were detected in various concentrations, but the most significant changes were observed in gallic acid, 4hydroxybenzoic acid, chlorogenic acid, epicatechin, p-coumaric acid, sinapic acid, 3-hydroxycinnamic acid and luteolin during processing steps.

The initial matrix of 7 processed parsley samples and 32 compounds (phenolic compounds and organic acids) was analysed using principal component analysis (PCA). The PCA of processed parsleys resulted in a two component model that explained by $70.27 \%$ variance (Fig.6). The first component accounted by $47.93 \%$, the second by $22.34 \%$. The correlation plots showed clustering of the processed parsleys in a 3 groups- fresh and steamblanched, and 1.5 min SB followed by MV drying; MV and convective dried parsleys; $3.0 \mathrm{~min}$ SB followed by MV drying.

In the first group (fresh, steam-blanched, $1.5 \mathrm{~min}$ steam-blanched followed by MV drying) corresponding compounds were ascorbic, tartaric, benzoic, fumaric and 3.4-dihydroxybenzoic acids, and (+)-catechin; in second group (convective and MV dried) parsleys corresponding compounds in highest concentrations were vanillin, salicylic, citric, syringic, chlorogenic, oxalic and 
succinic acids. The largest part of compounds corresponds to 3.0 min steamblanched followed by MV dried parsleys.

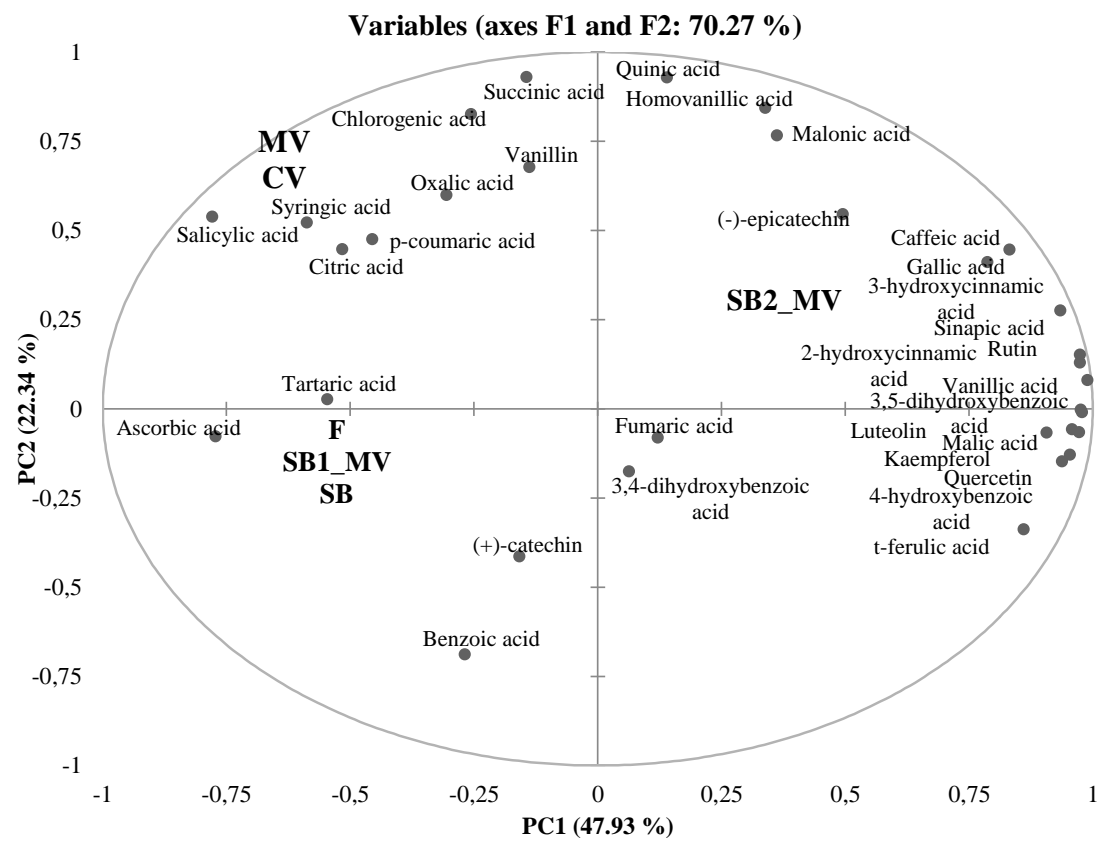

Fig. 6 PCA scores of processed parsleys and distribution of corresponding compounds /

6. att. Galveno komponentu analīzes apstrādātiem pētersīliem un izkliede atbilsošajiem savienojumiem

In processed celeries phenolic compounds detected at the highest concentrations were 4-hydroxybenzoic and sinapic acids, catechin, epicatechin, rutin, quercetin, luteolin and kaempferol and changes were observed.

The initial matrix of 7 processed celery samples and 32 compounds was analysed using principal component analysis (PCA). The PCA of processed celeries resulted into two component model that explained by $61.66 \%$ variance. The first component accounted by $40.33 \%$, the second by $21.33 \%$ (Fig.7). The correlation plots (Fig. 7) showed clustering of the processed celeries in a 4 groups- fresh and $1.5 \mathrm{~min}$ steam-blanched; 3.0 min steamblanched and $1.5 \mathrm{~min}$ SB followed by MV drying; MV and convective dried parsleys; 3.0 min SB followed by MV drying.

In fresh and 1.5 min steam-blanched celeries corresponding compounds in the highest amounts were detected ascorbic, succinic, benzoic, and citric, quinic, 2-hydroxycinnamic and 4-hydroxybenzoic acids. In convective dried celeries salicylic, homovanillic, malonic and p-coumaric acids corresponds; for 
MV dryer processed and $3.0 \mathrm{~min}$ steam-blanched celeries most of phenolics and organic acids were detected in the highest amounts.

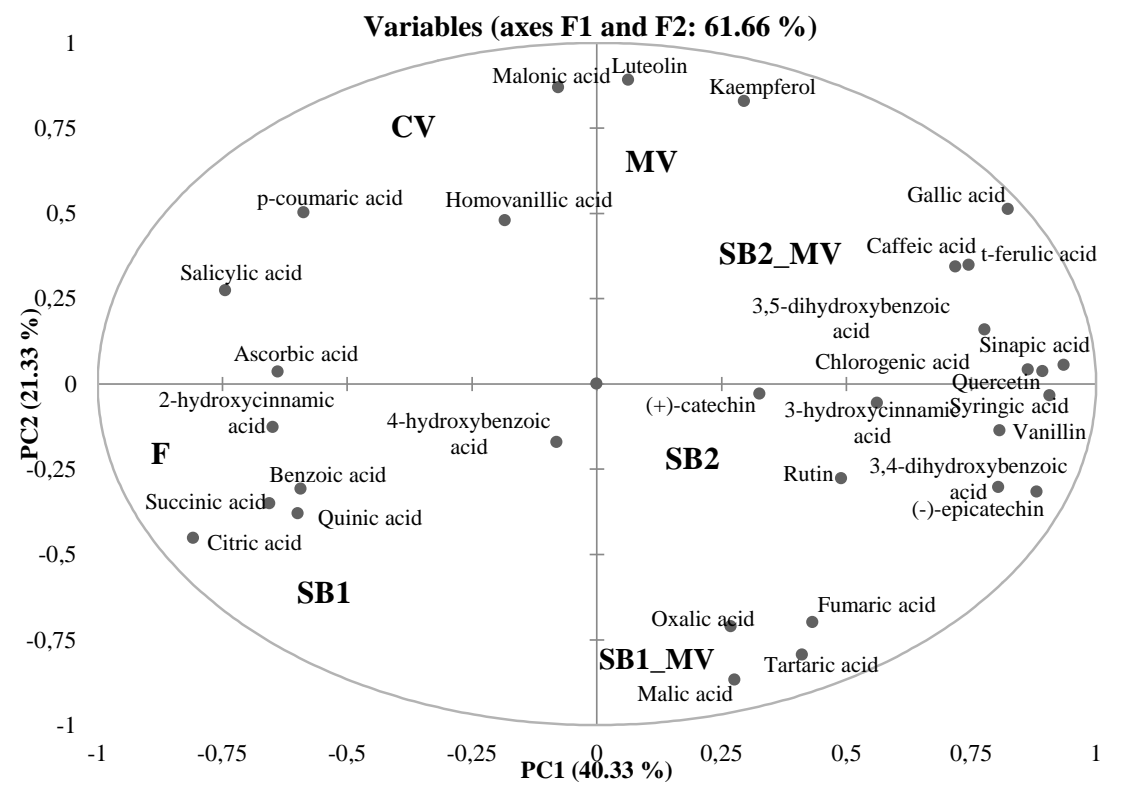

Fig.7. PCA scores of celeries and distribution of corresponding compounds/

7.att. Galveno komponentu analīzes rezultāti selerijām un atbilstošo savienojumu izkliede

Antiradical activity can be determined with various spectrophotometric methods. Mainly for activity determination in plant materials are used DPPH and ABTS radicals. In Apiaceae spices both with ABTS and DPPH radicals antiradical activity was determined in the highest amounts (Fig. 8).

Antiradical activity increased in spices with increasing in total phenolic content in all analysed samples after steam-blanching and drying.

The antioxidant capacity of plants may change after harvesting depending on processing and the storage conditions (Jimenez-Zamora et al., 2016).

It is concluded from various researches, that ABTS radical solution reacts not only with phenolic compounds, but also carotenoids and chlorophyll, while DPPH radical is more appropriate for determination activity for phenolic compounds. Reaction kinetics of phenolic compounds and ABTS ${ }^{*+}$ have been found to differ from that between phenolics and $\mathrm{DPPH}^{*}$ over a similar range of concentrations. Reactions of phenolics with ABTS radical cation are usually rapid, but the reactions with DPPH radical differ from compound to compounds (Katalinic et al., 2006). 

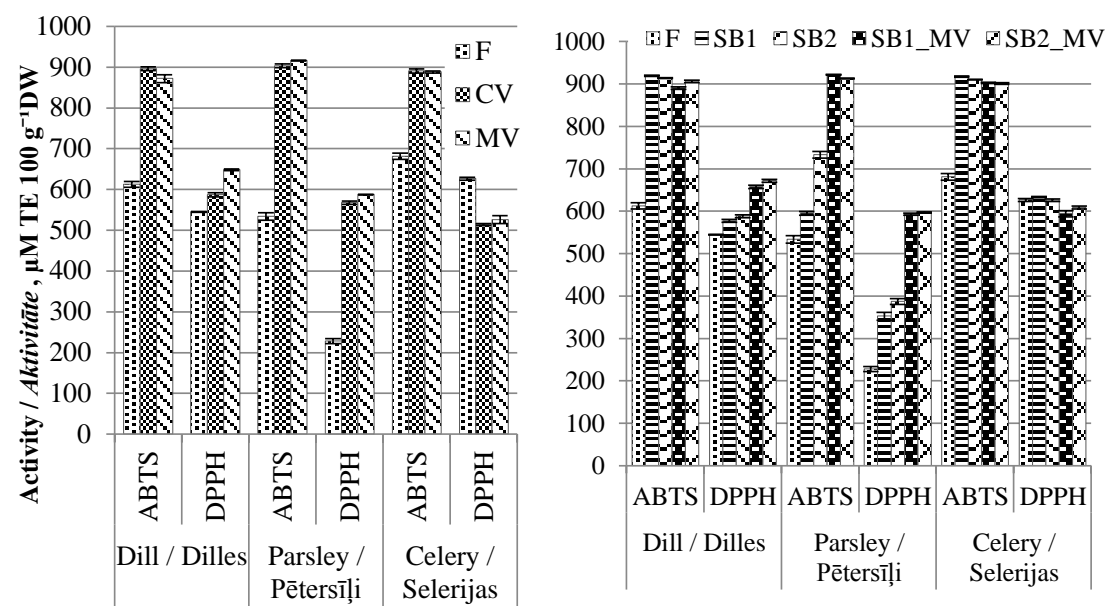

Fig.8 Antiradical activity in processed Apiaceae spices / 8. att. Antiradikāāā aktivitāte apstrādātos Apiaceae garšaugos

Main sugars were determined in Apiaceae spices and were observed in various concentrations, which changed after drying. Obtained results were used for integrated evaluation.

\section{Physical and chemical parameters in Apiacae vegetables (celery roots, carrots)}

Moisture content in celery roots was $88.95 \pm 0.89 \%$ and in carrots moisture content was $89.78 \pm 0.90 \%$, and steam-blanching did not significantly affected content. Using both convective and MV drying initial moisture content was decreased till less than $10 \%$.

Using long term steam-blanching process colour changes became more visible; the highest increase was observed with convective dried carrots and MV dried celery roots. Steam-blanching processing followed by MV drying helped to maintain colour. In fruits, the browning is caused mainly by enzymatic oxidation of endogenous phenols into quinones, which later are polymerized into brown products (colour changes occours) (Nunez-Mancilla et al., 2013).

Total carotenoid content of Apiaceae vegetables ranged differently and in celery roots was detected in smaller amounts than in carrots. Slight increase was observed in $1.5 \mathrm{~min}$ steam-blanched carrots, while longer steam-blanching processing gave decrease in carotenoid content. The highest increase was observed in MV dried carrots (Fig.9). 

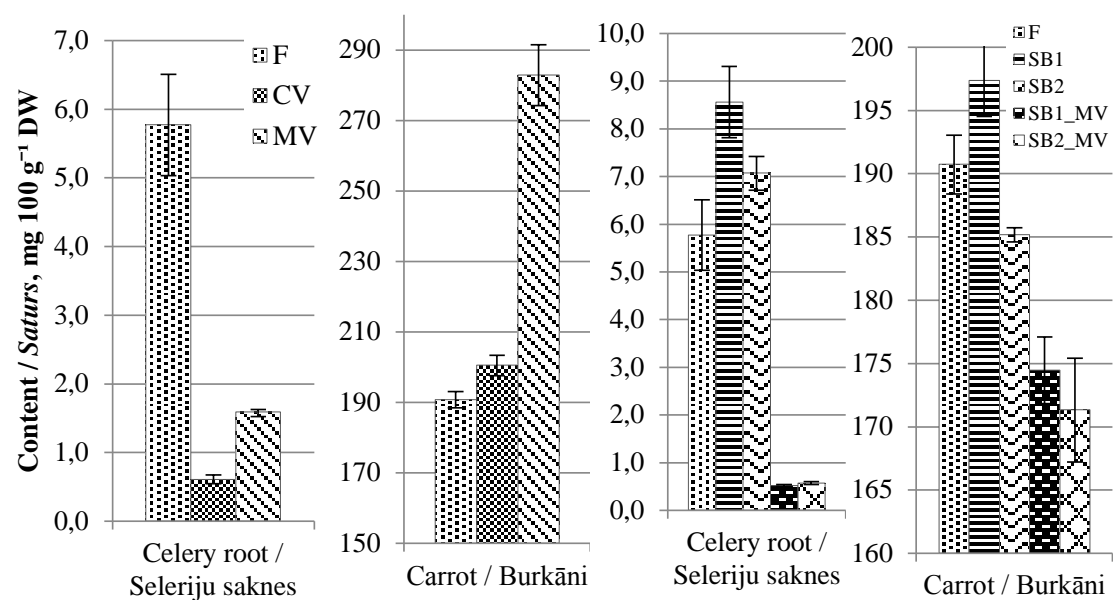

Fig.9. Total carotenoid content in celery roots and carrots

9. att. Kopējo karotinoūdu saturs seleriju saknēs un burkānos

In plant tissues carotenoids can exist in cis and trans forms and during processing some of trans forms are either lost or can be converted to cis forms and their derivatives, resulting in increase of total carotenoid content (Sharma et al., 2012). Decrease in carotenoid content is due to oxidation and it is depending on oxygen and can be stimulated by heat and light. Also it could lead to reduction of pigment levels (carotenoids in plants are responsible for yellow, red and red colours of vegetables) (Murador et al., 2014).

Main organic acids detected in the highest amounts in celery roots were malonic, citric, succinic, oxalic, tartaric, quinic and ascorbic acids and drying and steam-blanching affected initial amount (Table 8).

In fresh and processed celery roots tartaric and malic acids were not detected, while quinic acid was detected in 1.5 min steam-blanched and in 3.0 min steam-blanched followed by MV dried celery roots. Comparing quinic acid content in steam-blanched celery roots and steam-blanched followed by MV drying and MV drying increased initial content significantly. Oxalic acid in celery roots degraded more using short steam-blanching process, but longer thermal process maintained higher amount. Convective dried celery roots maintained higher oxalic acid amount than with MV dryer and pre-processing followed by MV drying gave higher acid content.

Malonic acid degraded significantly using short term steam processing, while lower decrease was observed using longer steam-blanching process. After convective drying initial malonic acid amount decreased, but MV dryer processing gave increase in total concentration.

Fumaric acid in celery roots was detected in low concentrations and processing significantly affected amount- short steam-blanching increased acid content and with longer process time increase was lower. Convective drying 
and 3.0 min steam-blanching followed by MV drying of celery roots gave the highest increase in fumaric acid.

Table 8 / 8.tabula

Organic acid composition in fresh, dried and steam-blanched celery roots / Organisko skābju sastāvs svaigās, kaltētās un ar tvaiku apstrādātās seleriju saknēs

\begin{tabular}{|l|c|c|c|c|c|c|c|}
\hline Acids & F & CV & MV & SB1 & SB2 & SB1_MV & SB2_MV \\
\hline Oxalic & 806.75 & 515.02 & 259.29 & 173.12 & 737.26 & 382.13 & 409.35 \\
\hline Tartaric & n.d. & n.d. & n.d. & n.d. & n.d. & n.d. & n.d. \\
\hline Quinic & n.d. & n.d. & n.d. & 795.92 & n.d. & n.d. & 2762.82 \\
\hline Malic & n.d. & n.d. & n.d. & n.d. & n.d. & n.d. & n.d. \\
\hline Malonic & 3363.54 & 2557.75 & 3873.69 & 169.12 & 2890.69 & 3524.18 & 3937.50 \\
\hline Ascorbic & 243.08 & 149.65 & 163.83 & 156.56 & 102.08 & 86.06 & 64.30 \\
\hline Citric & 5465.71 & 1940.91 & 3177.21 & 1658.36 & 1431.20 & 1276.16 & 212.43 \\
\hline Fumaric & 0.34 & 10.69 & n.d. & 3.61 & 1.01 & 1.83 & 33.69 \\
\hline Succinic & 7597.84 & 5339.17 & 192.60 & 8.00 & 1262.42 & 99.14 & 396.91 \\
\hline Salicylic & n.d. & 4.96 & 0.10 & 1.08 & 1.05 & 0.51 & 0.20 \\
\hline Benzoic & 3.97 & n.d. & 1.68 & 8.48 & 1.75 & 0.40 & 0.23 \\
\hline Total & 17481.23 & 10518.14 & 7668.41 & 2974.26 & 6427.47 & 5370.41 & 7817.43 \\
\hline
\end{tabular}

* results expressed as average amount with $10 \%$ standard deviation, $\mathrm{mg} 100 \mathrm{~g}^{-1}$ DW; n.d.- not detected; compounds gathered in Table $4 /$ rezultāti izteikti kā vidējais rezultāts ar $10 \%$ standartnovirzi; n.d- nav konstatēti; savienojumi apkopoti 4 .tabulā

Succinic acid during celery root processing degraded and higher temperatures for shorter time affected acid amount most significant. The lowest decrease was observed in 3.0 min steam-blanched and convective dried celery roots and MV energy negatively affected succinic acid content. Succinic acid solubility increases with increased temperatures and Gibbs energy (Mahali et al., 2017) and it is possible that due to decrease water activity of dried samples, acid degradation occours slower than in steam-blanched and MV dryer processed samples.

In carrots main organic acids were oxalic, tartaric and fumaric acids in different concentrations and with drying content changed (Table 9).

In carrots oxalic acid degraded with steam process significantly, and after convective drying process amount increased; MV drying did not affected oxalic acid in carrots, but with thermal pre-processing followed by MV drying content significantly decreased. Citric acid decreased with thermal process, but increased significantly with both convective and MV dryer processing of carrots. Tartaric acid started to degrade with short thermal process of carrots and longer process degraded initial amount. After convective drying acid content increased, while tartaric acid was not detected in MV dried carrots- preprocessing followed by MV drying helped to increase acid content compared to samples without thermal pre-processing.

Ascorbic acid in celery roots decreased significantly with steam-blanching process; convective drying and MV drying maintained the same amount as in steam-blanched samples. Using steam-blanching followed by MV drying in 
celery roots gave highest decrease. Ascorbic acid in carrots maintained more of initial amount using both steam-blanching and drying process.

Table 9 / 9. tabula

\section{Organic acid composition in fresh, dried and steam-blanched carrots / Organisko skābju sastāvs svaigos, kaltētos un ar tvaiku apstrādātos burkānos}

\begin{tabular}{|l|c|c|c|c|c|c|c|}
\hline Acids & F & CV & MV & SB1 & SB2 & SB1_MV & SB2_MV \\
\hline Oxalic & 316.46 & 953.78 & 331.94 & 228.07 & 139.49 & 146.82 & 89.75 \\
\hline Tartaric & 840.63 & 1553.01 & n.d. & 776.10 & 559.82 & 552.23 & 798.41 \\
\hline Quinic & n.d. & n.d. & 2898.31 & n.d. & 1030.42 & 3846.49 & 935.89 \\
\hline Malic & 168.19 & n.d. & n.d. & 301.42 & 1818.20 & n.d. & n.d. \\
\hline Malonic & n.d. & 817.10 & 1281.86 & n.d. & n.d. & 2757.70 & 1168.83 \\
\hline Ascorbic & 127.84 & 109.80 & 97.75 & 123.71 & 94.11 & 82.62 & 70.13 \\
\hline Citric & 1074.49 & 4163.34 & 1378.58 & 321.94 & 215.79 & 1108.75 & 60.42 \\
\hline Fumaric & 104.31 & 0.03 & n.d. & 9.98 & 22.07 & n.d. & 15.93 \\
\hline Succinic & 14.57 & 780.32 & 158.97 & 79.63 & n.d. & 24.39 & 420.77 \\
\hline Salicylic & n.d. & 3.36 & 0.18 & 0.60 & n.d. & 0.79 & 1.01 \\
\hline Benzoic & 1.83 & 0.59 & 0.29 & 0.42 & 0.78 & 0.27 & 0.13 \\
\hline Total & 2648.33 & 8381.33 & 6147.87 & 1841.87 & 3880.69 & 8520.07 & 3561.28 \\
\hline
\end{tabular}

* results expressed as average amount with $10 \%$ standard deviation, $\mathrm{mg} 100 \mathrm{~g}^{-1}$ DW; n.d.- not detected; compounds gathered in Table $4 /$ rezultâti izteikti kā vidējais rezultāts ar $10 \%$ standartnovirzi; n.d-nav konstatēti; savienojumi apkopoti 4.tabulā

Fructose and glucose of foods enchances vitamin $\mathrm{C}$ stability in temperature range $24-45{ }^{\circ} \mathrm{C}$ and lowers stability in the range $70-90{ }^{\circ} \mathrm{C}$. Increased processing temperatures lowers water activity and heightens non-enzymatic browning (Herbig \& Renard, 2017). The use of microwave in close systems have been proven to reduce the losses, due to fact that microwave irradiation reduces overheating problem that could also minimize the degradation of analytes (Biesaga, 2011).

Total phenolic content in Apiaceae vegetables varies with drying and steamblanching and were determined at lower concentrations than in Apiaceae spices (Fig.10).

Total phenolic content of celery roots were lower than in celery leaves and after steam-blanching increased minimally; after convective drying amount increased more than with MV dryer processing. Phenolic acids in celery roots were detected in lower concentrations than flavonoids. With steam-blanching process phenolic acids decreased less and with drying process decreased significantly. Flavonoids decreased in the same tendency as phenolic acids. Both phenolic acids and flavonoids maintained higher amount using MV dryer processing.

The total phenolic content in carrots minimally changed with steam processing, while with convective drying content significantly increased. After MV processing phenolic content increased less than with convective drying The phenolic acid content decreased with convective drying less than using MV drying, and steam-blanching helped to maintain phenolic acid content. 


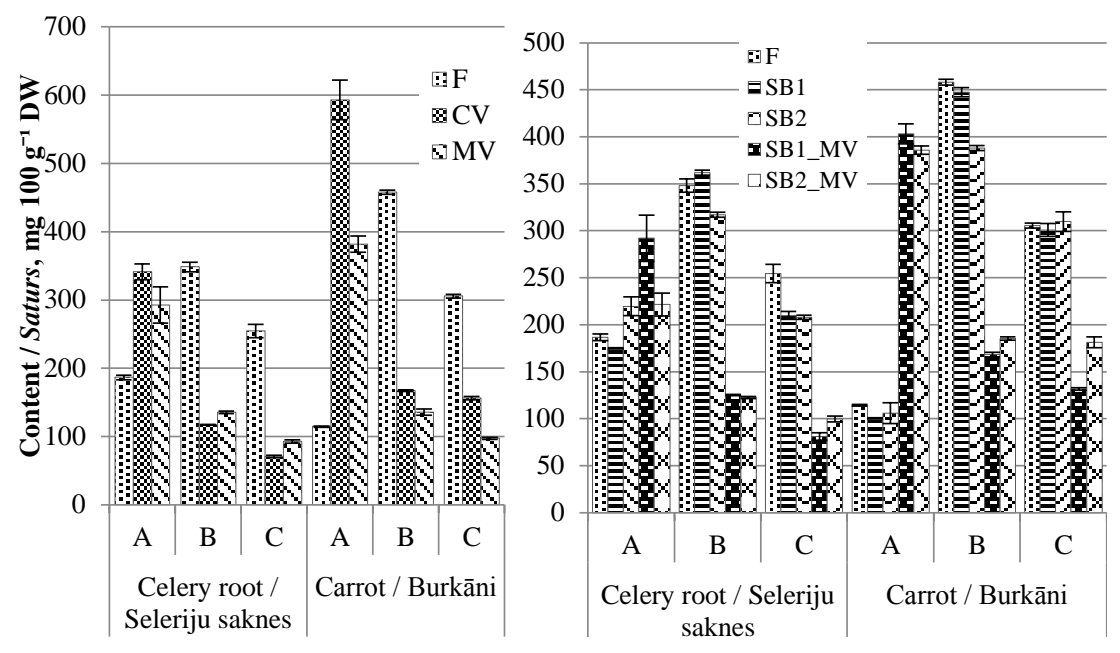

Fig.10 Total phenolic (A), flavonoid (B) and phenolic acid (C) content in Apiaceae vegetables /

10. att. Kopējo fenolu (A), flavonō̄du (B) un fenolskābju (C) saturs Apiaceae dārzeños

Many hypotheses have been applied for phenolic acid changes during cooking: partial release from bounded form leading to increase in the soluble one, a decrease of the soluble fraction due to thermal degradation and an increase of the bound form caused by interactions of phenolic acids with macromolecules of the food matrix (Zaupa et al., 2015). Is has been reported that polymerization due to heating or concentration during processing may also increase the total phenolic content of food materials (Tomas et al., 2017)

Phenolic compounds in processed celery roots like catechin, rutin, gallic, 3.4-dihydroxybenzoic, 4-hydroxybenzoic, sinapic, 2-hydroxycinnamic and 3-hydroxycinnamic acids were detected at highest concentrations and significant changes were observed.

Individual phenolic compounds and organic acids were categorised by used processing method and identified compounds. The initial matrix of 7 processed celery roots samples and 32 compounds was analysed using principal component analysis (PCA). The PCA of processed celery roots resulted into two component model that explained by $58.02 \%$ variance. The first component accounted by $32.22 \%$, the second by $25.80 \%$ (Fig. 11). The correlation plots (Fig.11) showed clustering of the processed celery roots in a 3 groups- fresh and steam-blanched; MV processed; and convective dried.

Coresponding compounds of fresh and steam-blanched celery roots were ascorbic, oxalic, succinic, citric, gallic and benzoic acids, and (+)-catechin; compounds of convective dried celery roots- kaempferol, salicylic, 3.4-dihydroxybenzoic, 3-hydroxycinnamic, chlorogenic, 4-hydroxybenzoic, 
p-coumaric, fumaric acids; compounds of MV processed celery roots- vanillin, rutin, quercetin, luteolin, (-)-epicatechin, sinapic, 3.5-dihydroxybenzoic, tferulic, 2-hydroxycinnamic, malonic, syringic, caffeic and quinic acids.

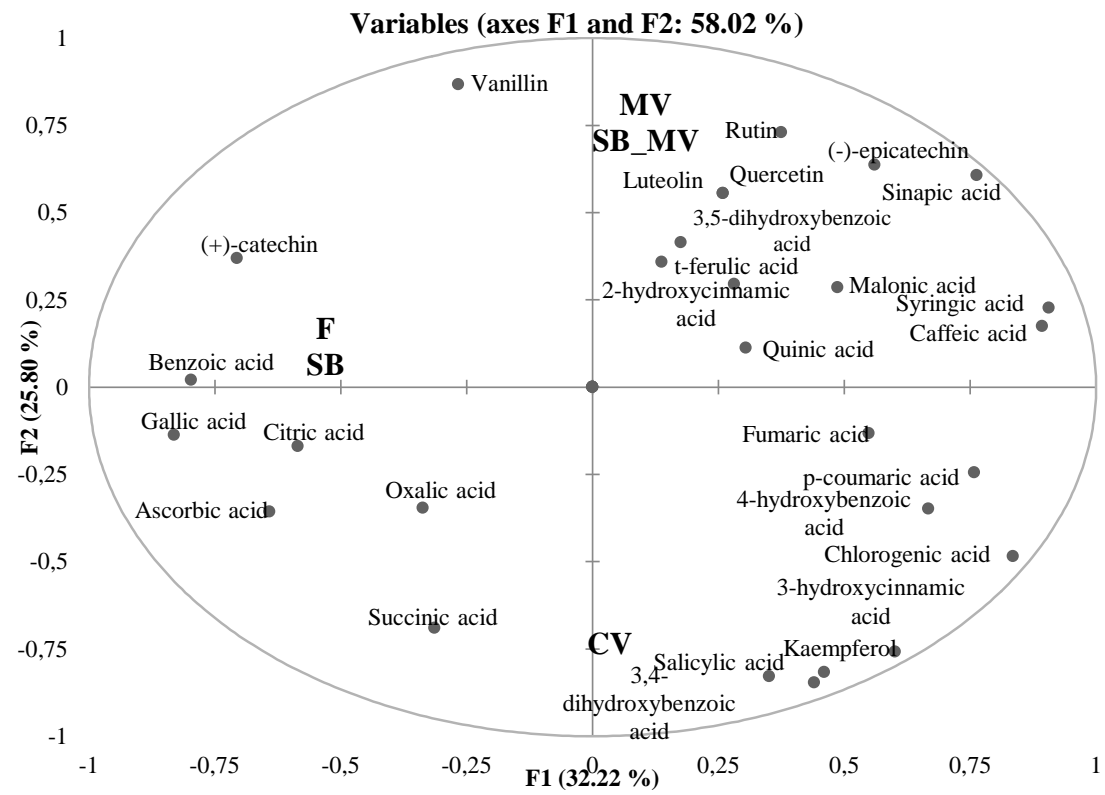

Fig.11 PCA analysis of celery roots and distribution of corresponding compounds/

\section{1. att. Galveno komponentu analīze seleriju saknēm un savienojumu sadalījumus}

From all analysed phenolic compounds of processed carrots, 3.4dihydroxybenzoic, 3.5-dihydroxybenzoic and sinapic acids, catechin and kaempferol were observed to change during processing.

Using principal component analysis, individual phenolic compounds and organic acids were categorised by used processing method and identified compounds. The initial matrix of 7 processed carrot samples and 32 compounds was analysed using principal component analysis (PCA). The PCA of processed carrots resulted into two component model that explained by $66.27 \%$ variance. The first component accounted by $44.24 \%$, the second by $22.03 \%$ (Fig.12). The correlation plots (Fig.12) showed clustering of the processed carrots in a 3 groups- fresh and steam-blanched; MV processed; and convective dried. 


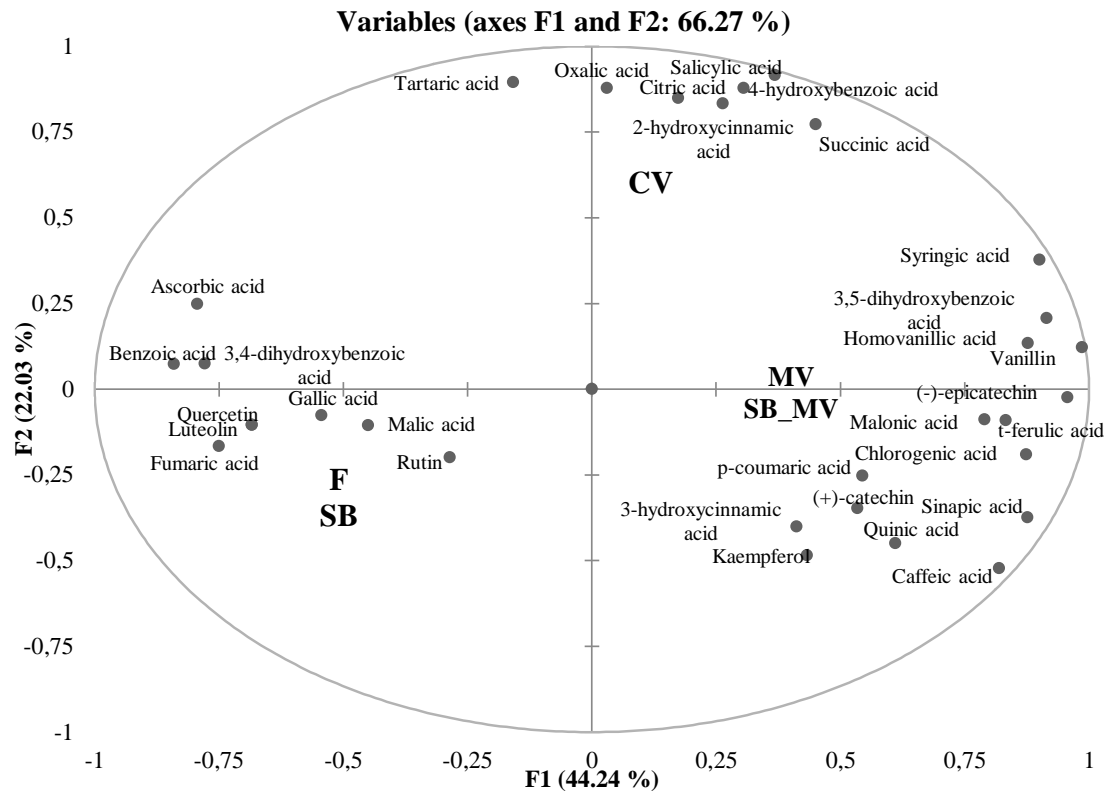

Fig.12 PCA analysis of carrots and distribution of corresponding compounds/

\section{2. att. Galveno komponentu analīze burkāniem un savienojumu sadalījumus}

Corresponding compounds of fresh and steam-blanched carrots were rutin, quercetin, luteolin, fumaric, malic, gallic, benzoic, ascorbic and 3.4dihydroxybenzoic acids; compounds of convective dried carrots were tartaric, oxalic, salicylic, citric, succinic, 4-hydroxybenzoic and 2-hydroxycinnamic acids. Corresponding compounds of MV dryer processed carrots were most of phenolic compounds and quinic and malonic acids.

Antiradical activity in Apiaceae vegetables with used radical varies differently and the highest activity was observed with ABTS radical and after drying significant increase was observed (Fig.13).

Increase of antiradical activity with DPPH using various blanching techniques compared to raw foods may be due to the fact that thermal blanching can destroy the cell wall of vegetables and by thus facilitate the antioxidants release (Wang et al., 2017).

Significant increase in antiradical activity was observed in vegetables after 3.0 min steam-blanching and drying processes. 

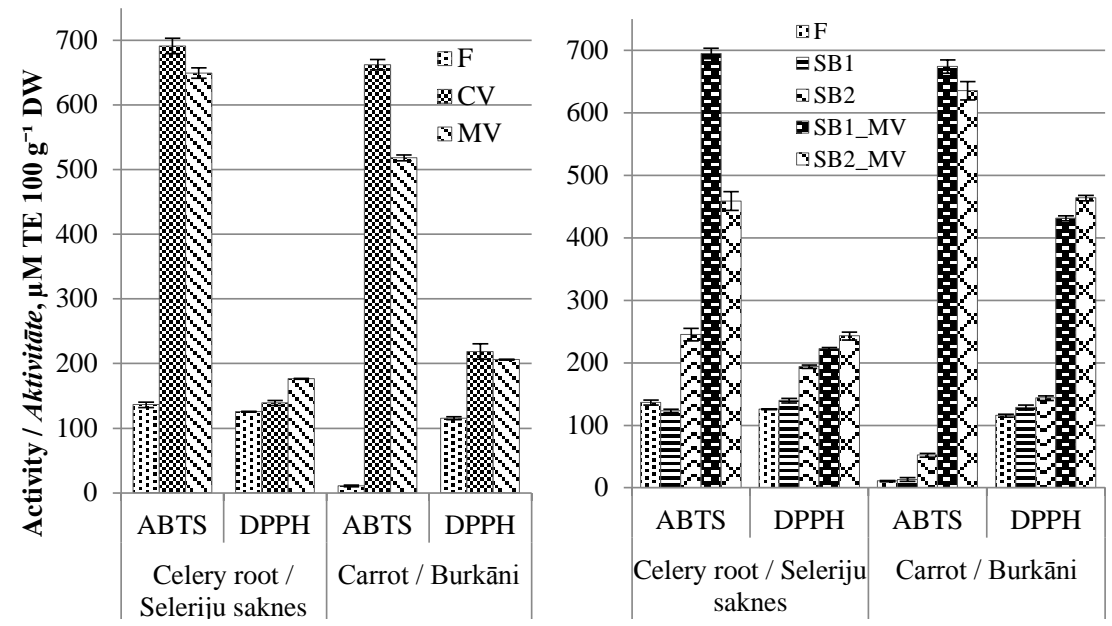

Fig.13 Antiradical activity in Apiaceae vegetables / 13. att. Antiradikālā aktivitāte Apiaceae dārzenos

Main sugars were determined in celery roots and carrots and after drying changes were observed.

\section{Physical and chemical parameters in Allium spices (leeks, onions, garlics)}

Moisture content in fresh leeks were $88.20 \pm 0.88 \%$, in fresh onions were $93.84 \pm 0.94 \%$ and in garlics $64.02 \pm 0.64 \%$ and steam-blanching minimally affected moisture. Using convective and MV drying moisture was decreased till less than $10 \%$.

Colour differences of Allim spices minimally changed using steamblanching process, while drying significantly altered colour. More visible changes $(\Delta \mathrm{E}>10)$ were observed in convective dried Allium spices, while MV processing gave less significant changes.

Total carotenoid content of fresh and dried Allium spices changed and total amount were determined in different concentrations (Fig.14).

Steam-blanching significantly increased total carotenoid amount in all analysed Allium spices, but after MV drying initial carotenoid content decreased in onions and garlics (Fig.15).

Total carotenoid content in leeks increased after steam-blanching process and using convective drying content significantly increased. With MV dryer process was observed higher increase than using convective drying. In onions and garlics carotenoids were detected in lower concentrations than in leeks and slightly increased after steam-blanching, but decreased with drying. 

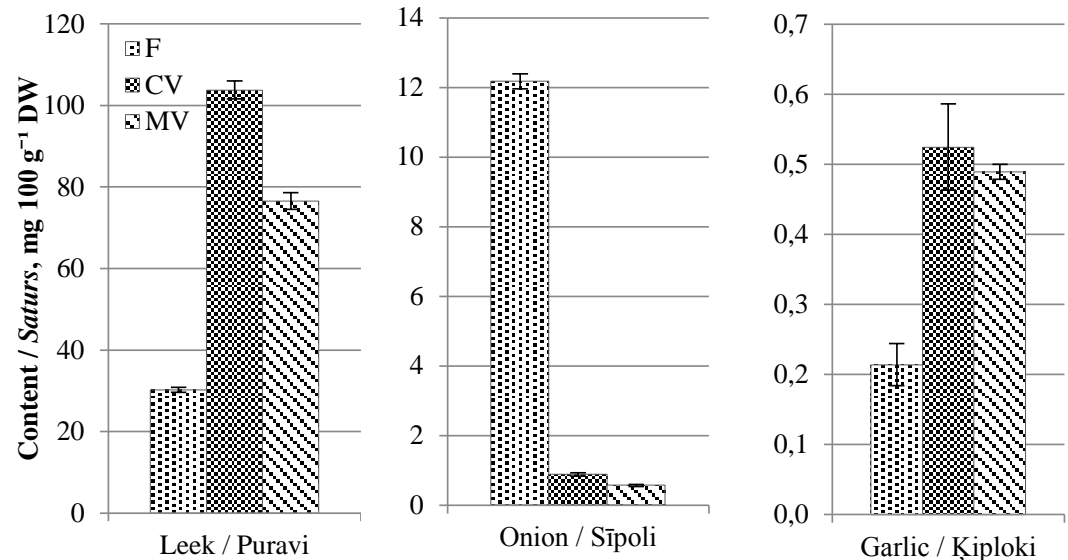

Fig.14 Total carotenoid content in fresh and dried Allium spices / 14.att. Kopējo karotinō̄du saturs svaigos un kaltētos Allium garšaugos
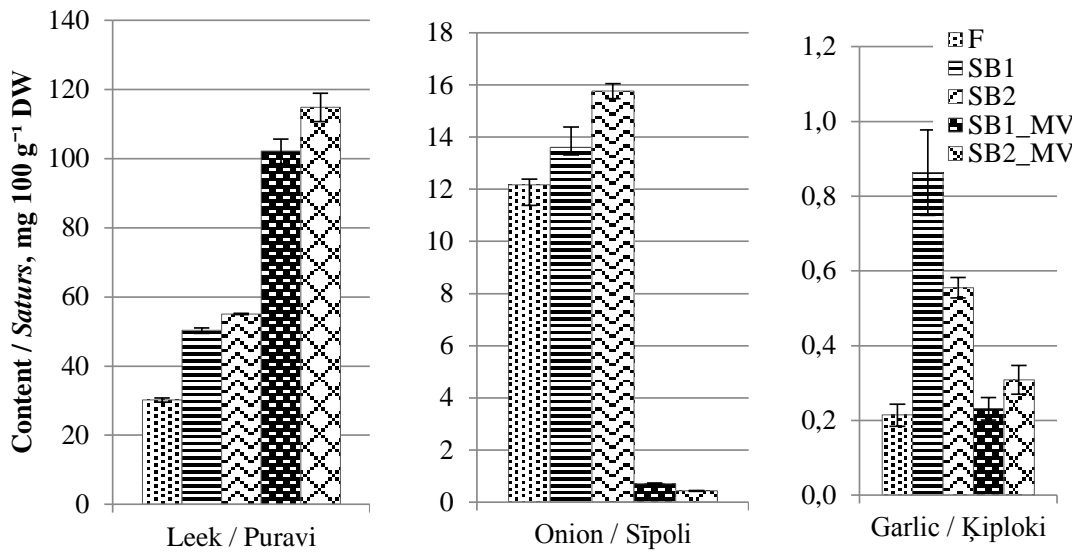

Fig.15 Steam-blanching effect on total carotenoid content in MV dried Allium spices /

15.att. Apstrādes ar tvaiku ietekme uz kopējo karotinō̄du saturu MV kaltētos Allium garšaugos

Main organic acids determined in leeks were oxalic, quinic, malonic, citric and succinic acids in various concentrations and content changed with processing (Table 10).

In leeks oxalic acid significantly decreased with steam-blanching process, while drying process increased the initial amount using convective drying and minimally content altered using MV drying; longer pre-processing followed by MV drying gave the same increase as using convective drying. Quinic acid in 
leeks significantly increased using all processing methods- the highest increases was observed in short steam-blanched leeks and in $3.0 \mathrm{~min}$ steam-blanched followed by MV dried leeks. Short term pre-processing followed by MV drying gave lower quinic acid amount than in steam-blanched leeks and maintained low amount. It may be concluded that MV drying gave negative effect on quinic acid amount in leeks.

Table 10 / 10. tabula

\section{Organic acid composition in fresh, dried and steam-blanched leeks / Organisko skābju sastāvs svaigos, kaltētos un ar tvaiku apstrādātos puravos}

\begin{tabular}{|l|c|c|c|c|c|c|c|}
\hline Acids & F & CV & MV & SB1 & SB2 & SB1_MV & SB2_MV \\
\hline Oxalic & 101.85 & 316.31 & 103.89 & 75.92 & 73.17 & 61.12 & 303.46 \\
\hline Tartaric & n.d. & 532.52 & 655.44 & 127.63 & 995.97 & 526.51 & n.d. \\
\hline Quinic & 94.44 & 700.83 & 956.75 & 1889.45 & n.d. & 444.16 & 1785.13 \\
\hline Malic & n.d. & 1200.59 & 1238.39 & 935.44 & 1391.46 & n.d. & n.d. \\
\hline Malonic & 60.10 & 1548.86 & 3213.06 & n.d. & n.d. & 1529.91 & 1020.35 \\
\hline Ascorbic & 152.68 & 140.57 & 144.91 & 143.74 & 142.02 & 120.98 & 97.78 \\
\hline Citric & 1532.55 & 696.38 & 963.81 & 363.83 & 648.02 & 267.14 & 745.61 \\
\hline Fumaric & 0.46 & 0.27 & 1.46 & 23.83 & 0.45 & 1.51 & 0.50 \\
\hline Succinic & 36.41 & 1089.75 & n.d. & 45.98 & 34.29 & 216.27 & 622.65 \\
\hline Salicylic & n.d. & 7.65 & 1.55 & 0.42 & 0.53 & 4.10 & 33.40 \\
\hline Benzoic & 0.79 & n.d. & n.d. & 0.23 & n.d. & 0.04 & 0.10 \\
\hline Total & 1979.27 & 6233.73 & 7279.26 & 3606.47 & 3285.89 & 3171.75 & 4608.98 \\
\hline
\end{tabular}

* results expressed as average amount with $10 \%$ standard deviation, mg $100 \mathrm{~g}^{-1} \mathrm{DW}$; n.d.- not detected; compounds gathered in Table 4/ rezultāti izteikti kā vidējais rezultāts ar $10 \%$ standartnovirzi; n.d-nav konstatēti; savienojumi apkopoti 4.tabulā

Malonic acid in leeks was determined in low concentrations and thermal process degraded initial amount, while with drying content increased. Citric acid in leeks degraded with thermal and drying processes, but highest decrease was observed in $1.5 \mathrm{~min}$ steam-blanched and in $1.5 \mathrm{~min}$ steam-blanched followed by MV dried samples. Succinic acid content in leek samples minimally increased using steam processing and with drying initial content increased. Salicylic acid in leeks increased slowly using steam-blanching, and faster- with drying; most effective method for increase of acid was observed in convective dried and 3.0 min steam-blanched followed by MV dried leeks.

Main organic acids determined in onions were tartaric, oxalic, malonic and fumaric acids in different concentrations and after processing content changed (Table 11). Quinic acid in convective dried onions was determined in higher concentration than in MV dried onions and pre-processing followed by MV drying gave higher quinic acid content than in MV dried samples.

Oxalic acid minimally altered after convective drying of onions, but after MV drying content decreased; short pre-processing followed by MV drying gave the lowest decrease and longer pre-processing degraded acid more. After drying, in MV dried onions tartaric acid was degraded, while in convective dried and in pre-processed followed by MV dried onions acid was not observed. 
Malonic acid after short steam-blanching significantly decreased and longer time degraded acid; after convective drying acid amount did not changed, but MV drier processing altered total content. Significant malonic acid increase was observed in MV drying and pre-processing degraded acid compared to MV dried onions amount

Table $11 / 11$. tabula

Organic acid composition in fresh, dried and steam-blanched onions / Organisko skābju sastāvs svaigos, kaltētos un ar tvaiku apstrādātos sīpolos

\begin{tabular}{|l|c|c|c|c|c|c|c|}
\hline Acids & F & CV & MV & SB1 & SB2 & SB1_MV & SB2_MV \\
\hline Oxalic & 474.66 & 474.79 & 383.13 & 370.66 & 547.61 & 438.75 & 238.69 \\
\hline Tartaric & 1542.64 & n.d. & 817.77 & 1178.39 & 2256.15 & n.d. & n.d. \\
\hline Quinic & n.d. & 6689.54 & 1058.05 & n.d. & n.d. & 3380.46 & 4329.66 \\
\hline Malic & n.d. & n.d. & n.d. & n.d. & n.d. & n.d. & n.d. \\
\hline Malonic & 1247.42 & 1277.67 & 1822.47 & 22.93 & n.d. & 1492.82 & 1147.93 \\
\hline Ascorbic & 100.32 & 80.00 & 54.87 & 23.59 & 25.25 & 20.46 & 13.09 \\
\hline Citric & 281.97 & 493.16 & 899.91 & 461.89 & 664.92 & 398.87 & 294.18 \\
\hline Fumaric & 34.73 & 20.44 & 13.59 & 1.23 & 1.03 & 32.76 & 32.58 \\
\hline Succinic & 441.59 & n.d. & 653.54 & 22.11 & n.d. & 614.74 & n.d. \\
\hline Salicylic & 24.63 & 7.73 & 3.71 & 25.88 & 15.12 & 3.96 & 0.22 \\
\hline Benzoic & 0.23 & 0.05 & n.d. & n.d. & 0.32 & 0.09 & 0.04 \\
\hline Total & 4148.19 & 9043.39 & 5707.04 & 2106.67 & 3510.40 & 6382.91 & 6056.39 \\
\hline
\end{tabular}

* results expressed as average amount with $10 \%$ standard deviation, $\mathrm{mg} 100 \mathrm{~g}^{-1}$ DW; n.d.- not detected; compounds gathered in Table 4/ rezultāti izteikti kā vidējais rezultāts ar $10 \%$ standartnovirzi; $n$.d- nav konstatēti; savienojumi apkopoti 4 .tabulā

During onion processing citric acid increased and highest increase was observed in 3.0 min steam-blanched and in MV dried onions. It is possible that steam-blanching and then following microwave energy in vacuum degrades citric acid. Fumaric acid degraded during steam-blanching and convective drying and MV drying maintained higher amount of acid; pre-processing followed by MV drying maintained almost the same amount of acid as in fresh onions.

Main organic acids determined in garlics were tartaric, quinic, malonic and succinic acid at different concentrations (Table 12). Malic acid was not detected in processed garlics, but in dried garlics tartaric acid was not observed. Tartaric acid increased with steam-blanching and drying degraded acid in garlic samples. Quinic acid in garlics degraded, but increase was observed in convective and MV drier processed samples. The highest increase of quinic acid was determined in convective dried garlics and in $1.5 \mathrm{~min}$ steam-blanched followed by MV drying of garlics. Increase of quinic acid may be explained by chlorogenic acid derivative degradation due to thermal and non-thermal processing, which may lead into formation of coumaric acid and quinic acid (Petersen et al., 2009).

Malonic acid in garlics increased with steam-blanching and drying affected acid content similary. Pre-processing followed by MV drying gave the highest increase of malonic acid from all used processing methods. 
Succinic acid was one of acids determined in highest amounts in garlics with tendency to decrease in most of used processing methods.

Table 12 / 12. tabula

\section{Organic acid composition in fresh, dried and steam-blanched garlics / Organisko skābju sastāvs svaigos, kaltētos un ar tvaiku apstrādātos ķiplokos}

\begin{tabular}{|l|c|c|c|c|c|c|c|}
\hline Acids & F & CV & MV & SB1 & SB2 & SB1_MV & SB2_MV \\
\hline Oxalic & 803.59 & 910.48 & 885.45 & 892.66 & 829.60 & 814.68 & 830.76 \\
\hline Tartaric & 608.04 & n.d. & n.d. & 851.93 & 992.47 & n.d. & n.d. \\
\hline Quinic & 1565.95 & 3473.74 & 2279.69 & 1204.65 & 1376.40 & 2569.60 & 1769.54 \\
\hline Malic & n.d. & n.d. & n.d. & n.d. & n.d. & n.d. & n.d. \\
\hline Malonic & 124.73 & 184.27 & 290.66 & 319.00 & 572.24 & 346.82 & 841.04 \\
\hline Ascorbic & 75.57 & 41.93 & 61.55 & 63.49 & 62.13 & 41.70 & 32.26 \\
\hline Citric & 215.04 & 498.07 & 178.63 & 340.88 & 418.81 & 379.93 & 286.12 \\
\hline Fumaric & 4.82 & 0.14 & 1.56 & 0.11 & 2.12 & 1.16 & 0.81 \\
\hline Succinic & 513.54 & 613.52 & 244.56 & 266.77 & 102.43 & 109.33 & 132.57 \\
\hline Salicylic & 14.08 & n.d. & n.d. & 0.51 & n.d. & 0.46 & 0.72 \\
\hline Benzoic & n.d. & n.d. & n.d. & n.d. & n.d. & 0.07 & 0.05 \\
\hline Total & 3925.36 & 5722.15 & 3942.10 & 3940.02 & 4356.20 & 4263.75 & 3893.88 \\
\hline
\end{tabular}

* results expressed as average amount with $10 \%$ standard deviation, mg $100 \mathrm{~g}^{-1} \mathrm{DW}$; n.d.- not detected; compounds gathered in Table 4/ rezultāti izteikti kā vidējais rezultāts ar $10 \%$ standartnovirzi; n.d- nav konstatēti; savienojumi apkopoti 4.tabulā

Salicylic acid in garlics was not stable under thermal process and was not detected in 3.0 min steam-blanched samples. In convective dried and MV dried garlics acid was under detection limit, but pre-processing followed by MV drying had positive effect on salicylic acid.

Ascorbic acid of leeks minimally changed with steam-blanching and drying process, while steam-blanching followed by MV drying decreased content. Ascorbic acid content in onions decreased significantly using steam-blanching process; with convective drying amount decreased less than using MV dryer processing. In garlics ascorbic acid minimally decreased with steam- blanching, and with convective drying content decreased more than using MV dryer. Water-soluble vitamins (including vitamin C) decreases by partially oxidizing during blanching process and excessive loss is observed by various drying methods (Roongruangsri \& Bronlund, 2015)

Total phenolic content, phenolic acid and flavonoid content of fresh and dried Allium spices were detected in various concentrations and drying method affected amount differently (Fig.16)

In leeks with short steam-blanching total amount minimally changed, but longer thermal process increased amount. Using convective drying the total phenolic content increased more than with MV dryer processing. Phenolics in onions and garlics decreased with steam-blanching, but after drying process significantly increased. 


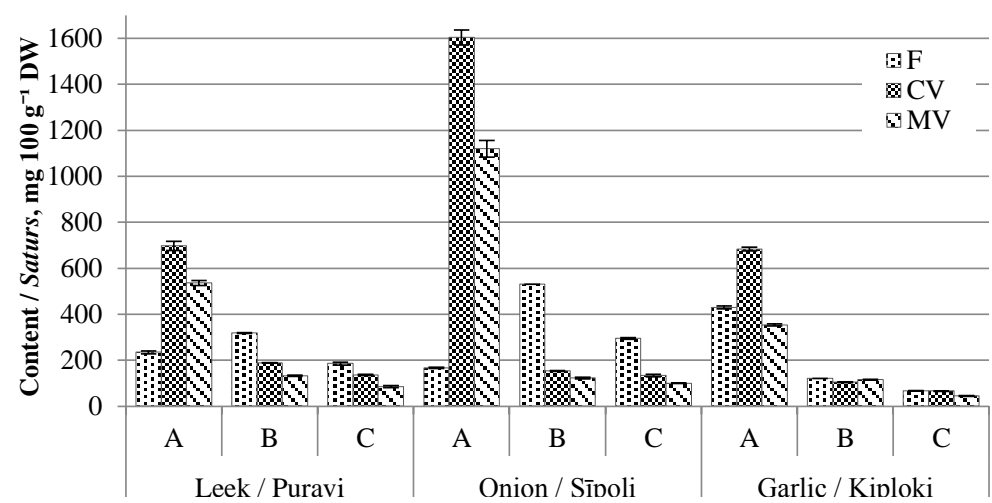

Fig.16 Total phenolic (A), flavonoid (B) and phenolic acid (C) content in fresh and dried Allium spices /

16.att. Kopējais fenolu (A), flavonō̄du (B) un fenolskābju (C) saturs svaigos un kaltētos Allium garšaugos

Steam-blanching slightly increased total phenolic content and after drying significant increase was determined in leeks and onions (Fig.17).

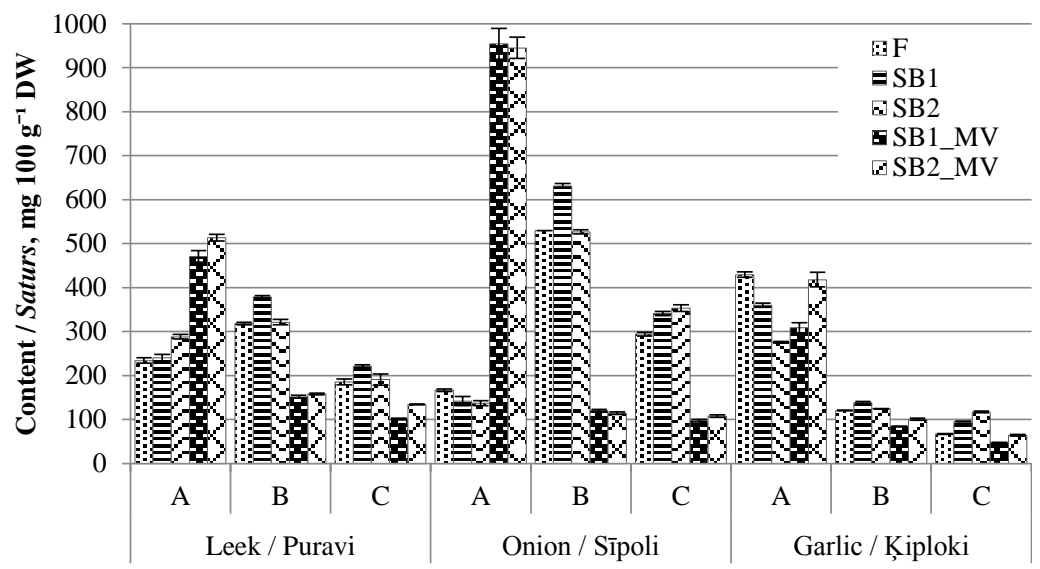

Fig.17 Steam-blanching effect on total phenolic (A), flavonoid (B) and phenolic acid (C) content in MV dried Allium spices

17.att. Apsträdes ar tvaiku ietekme uz kopējo fenolu (A), flavonō̄du (B) un fenolskäbju (C) saturu MV kaltētos Allium garšaugos

Total phenolic acid content in leeks, onions and garlics increased after steam-blanching and with drying decreased. Total flavonoids of Allium spices were detected in higher concentrations than phenolic acids. Similar to phenolic acids, total flavonoid content with steam-blanching process increased, while with drying process concentrations decreased. Steam-blanching as pre- 
treatment for MV drying helped to maintain higher concentrations of flavonoids in analysed spices.

Short and rapid heating may cause inactivation of oxidative enzymes and contribute to better preservation of phenolic compounds (Samoticha et al., 2016). According to Nawirska-Olszanska et al. (2017) using fountainmicrowave drying with 2 energy levels (100 and $250 \mathrm{~W})$ total phenolic content and their antiradical activity decreased significantly- higher energy level negatively affects phenolic compound content.

Phenolic compounds detected in leeks at the highest concentrations and changed during processing were catechin, rutin, luteolin, gallic, 3.4dihydroxybenzoic, chlorogenic, sinapic and 2-hydroxycinnamic acids (Fig. 18).

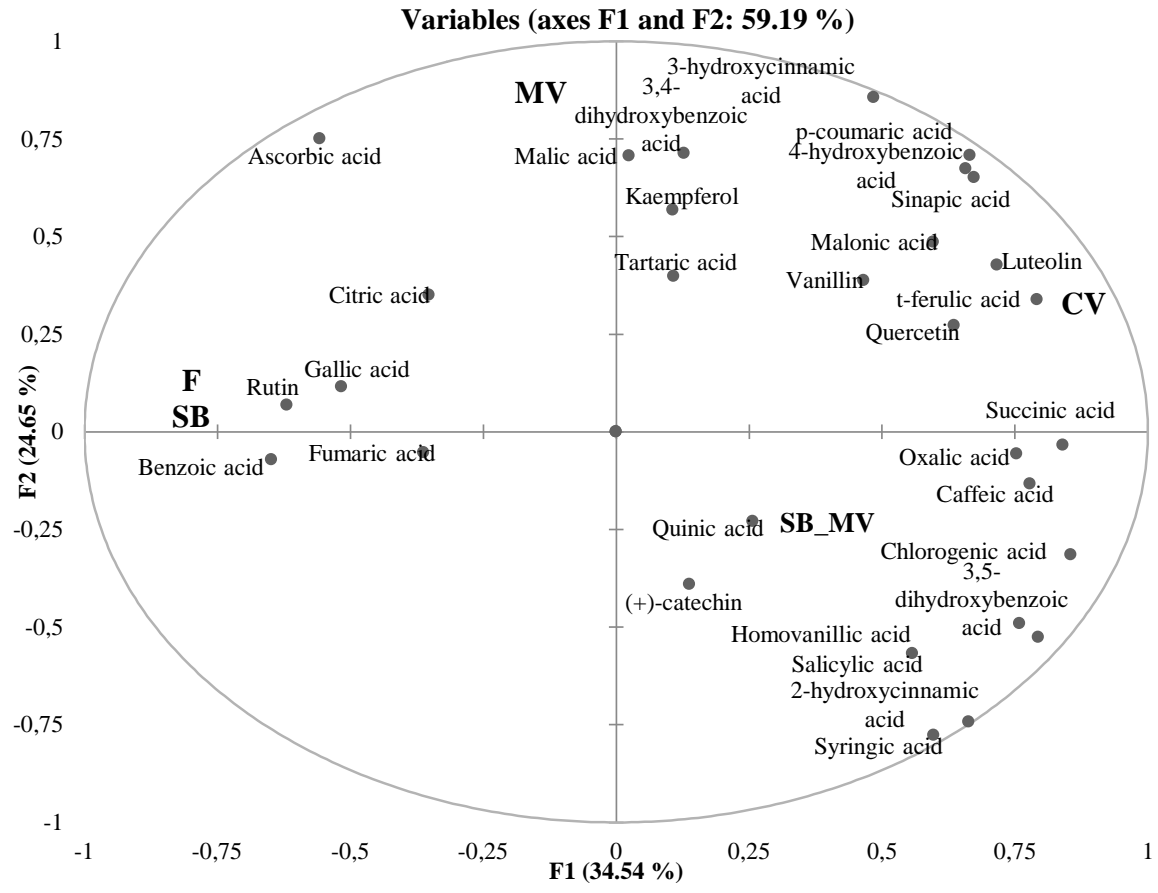

Fig.18 PCA analysis of leeks and distribution of corresponding compounds/

18.att.Galveno komponentu analīze puraviem un atbilstošo savienojumu sadalijums

The initial matrix of 7 processed leek samples and 32 compounds (phenolic compounds and organic acids) was analysed using principal component analysis (PCA). The PCA of processed leeks resulted into two component model that explained by $59.19 \%$ variance. The first component accounted by $34.54 \%$, the second by $24.65 \%$. The correlation plots showed clustering of the 
processed carrots in a 3 groups- fresh and steam-blanched; MV and convective dried; steam-blanched followed by MV dried samples (Fig.18).

Corresponding compounds of fresh and steam-blanched leeks were rutin, benzoic, fumaric, gallic, citric and ascorbic acids; compounds of convectie and MV dried leeks were luteolin, quercetin, vanillin, kaempferol, malic, malonic, tartaric, t-ferulic, sinapic, p-coumaric, 4-hydroxybenzoic, 3.4-dihydroxybenzoic and 3-hydroxycinnamic acids. Compounds of steam-blanched followed by MV dried leeks were succinic, oxalic, caffeic, quinic, chlorogenic, 3.5dihydroxybenzoic, homovanillic, salicylic, 2-hydroxycinnamic and syringic acids and (+)-catechin.

Phenolic compounds like gallic acid, catechin, ferulic acid, rutin and quercetin were detected at the highest concentrations and was observed significant changes during processing of onions (Fig. 19).

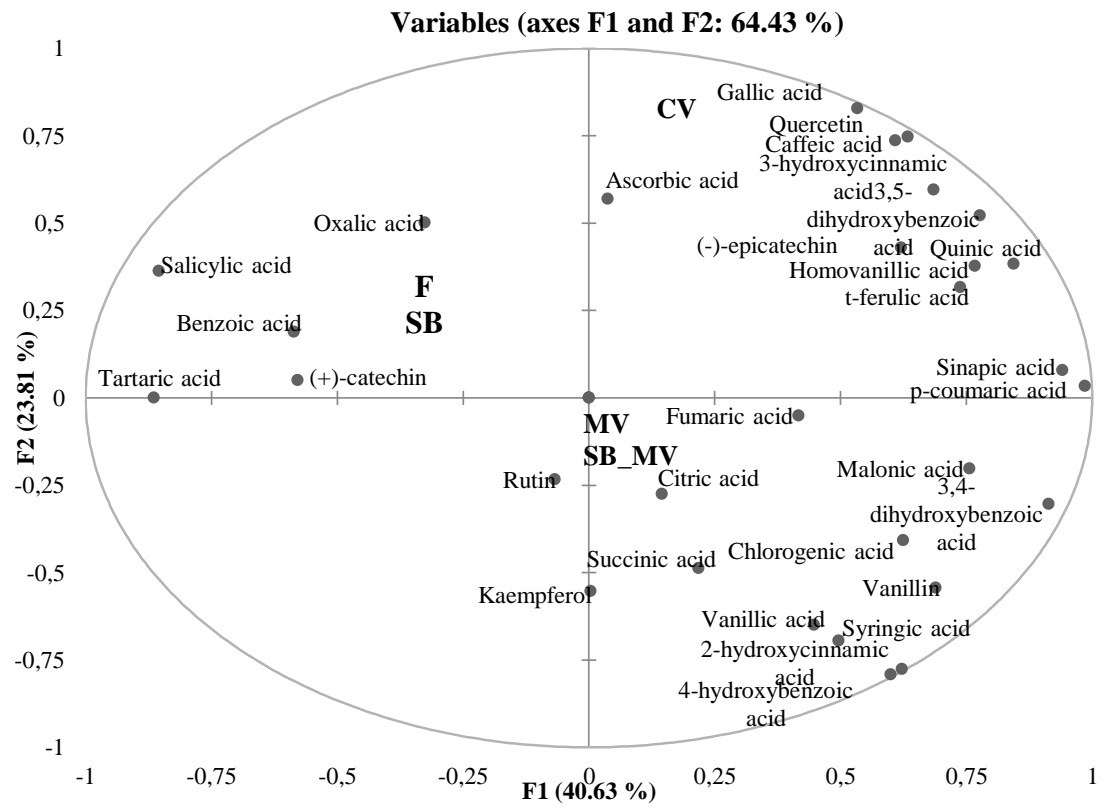

\section{Fig.19 PCA analysis of onion and distribution of corresponding compounds/ \\ 19.att.Galveno komponentu analīze sīpoliem un atbilstošo savienojumu sadalïums}

The initial matrix of 7 processed onion samples and 32 compounds (phenolic compounds and organic acids) was analysed using principal component analysis (PCA). The PCA of processed onions resulted into two component model that explained by $64.43 \%$ variance. The first component accounted by $40.63 \%$, the second by $23.81 \%$. The correlation plots (Fig.19) 
showed clustering of the processed onions in a 3 groups- fresh and steamblanched; MV dryer processed; convective dried samples.

Corresponding compounds of fresh and steam-blanched onions were (+)catechin, rutin, kaempferol, tartaric, benzoic, salicylic and oxalic acids. Convective dried onions compounds were quercetin, (-)-epicatechin, ascorbic, gallic, quinic, t-ferulic, homovanillic, 3.5-dihydroxybenzoic, 3-hydroxycinamic and caffeic acids. Compounds detected in the highest concentrations of MV dryer processed onions were vanillin, fumaric, citric, malonic, 3.4dihydroxybenzoic, chlorogenic, succinic, vanillic, syringic, 2-hydroxycinnamic and 4-hydroxybenzic acids.

Individual phenolic compound concentrations of processed garlics were determined in different amounts and processing affected catechin, 4hydroxybenzoic acid, syringic acid, vanillin, t-ferulic acid, 3-hydroxycinnamic acid and kaempferol significantly (Fig. 20).

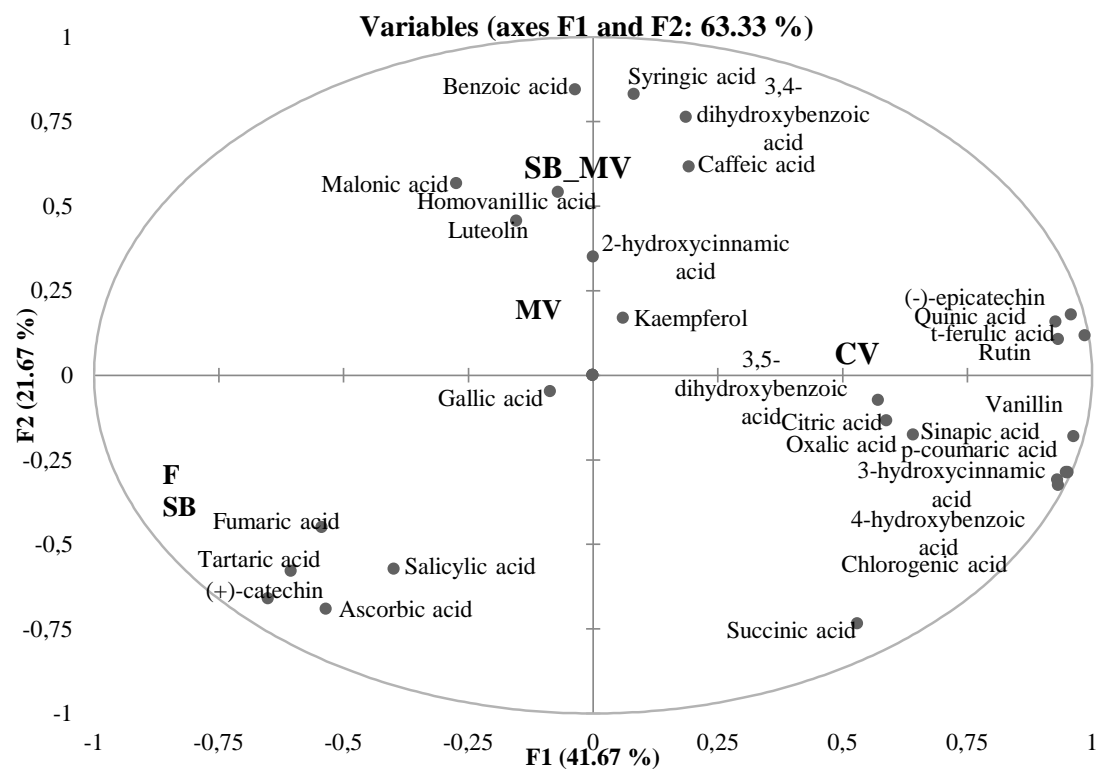

\section{Fig.20 PCA analysis of garlics and distribution of corresponding compounds/ \\ 20 att. Galveno komponentu analīze ķiplokiem un atbilstošo savienojumu sadalijums}

The initial matrix of 7 processed garlic samples and 32 compounds was analysed using principal component analysis (PCA). The PCA of processed garlics resulted into two component model that explained by $63.33 \%$ variance. The first component accounted by $41.67 \%$, the second by $21.67 \%$. The correlation plots (Fig.20) showed clustering of the processed garlics in a 3 
groups- fresh and steam-blanched; MV and convective dried; steam-blanched followed by MV dried samples. Fresh and steam-blanched garlics contain (+)catechin, tartaric, fumaric, salicylic, ascorbic and gallic acids at the highest concentrations. Corresponding compounds detected at highest concentrations of MV drier processed garlics were kaempferol, luteolin, malonic, homovanillic, benzoic, syringic, 3.4-dihydroxybenzoic, caffeic and 2-hydroxycinnamic acids. Convective dried garlics contain (-)-epicatechin, rutin, vanillin, quinic, t-ferulic, 3.5-dihydroxybenzoic, citric, oxalic, sinapic, p-coumaric, 3-hydroxycinnamic, 4-hydroxybenzoic, chlorogenic and succinic acids in the highest concentrations.

Antiradical activity in Allium spices increased with steam-blanching and drying (Fig.21).
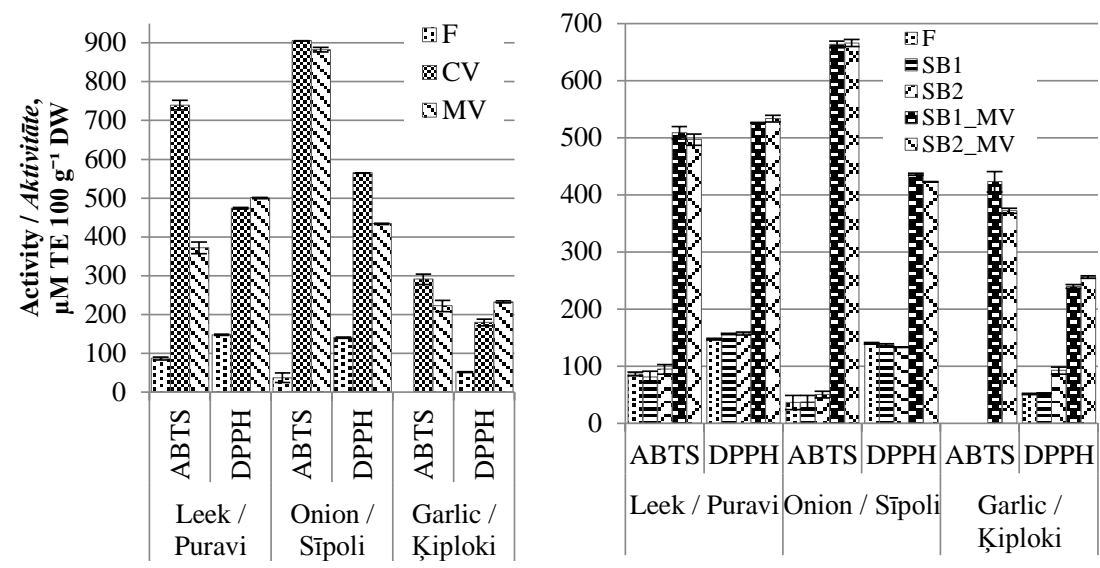

Fig.21 Antiradical activity in Allium spices / 21.att. Antiradikālā aktivitāte Allium garšaugos

From analysed Allium spices, the highest increase of antiradical activity was observed in onions and leeks.

Main sugars were determined in analysed samples and with drying initial content changed. Obtained results were used for integrated evaluation.

\section{Integrated evaluation of dried vegetables and spices}

Based on the results described in chapter 1, 2 and 3, for each dried vegetable and spice integrated evaluation was performed for obtaining product with the highest biological value. Many factors were assessed and high contribution coefficients $\left(\omega_{\mathrm{i}}\right)$ were given to fructose $\left(\mathrm{g} 100 \mathrm{~g}^{-1}\right)$, glucose $(\mathrm{g} 100$ $\mathrm{g}^{-1}$ ), total phenolics ( $\mathrm{mg} 100 \mathrm{~g}^{-1}$ ), and lower contribution coefficient was given to colour difference $(\Delta \mathrm{E})$. If the colour of final product is considered as a quality indicator, the colour parameters can be used to optimise the drying conditions and minimize the degradation of important compounds (Aral \& Vildan Bese, 2016). 
The integrated evaluation shows that steam-blanching followed by MV drying of dills (Fig.22 a) had lowest integrated value and was the best drying method for obtaining dills with highest biological value.

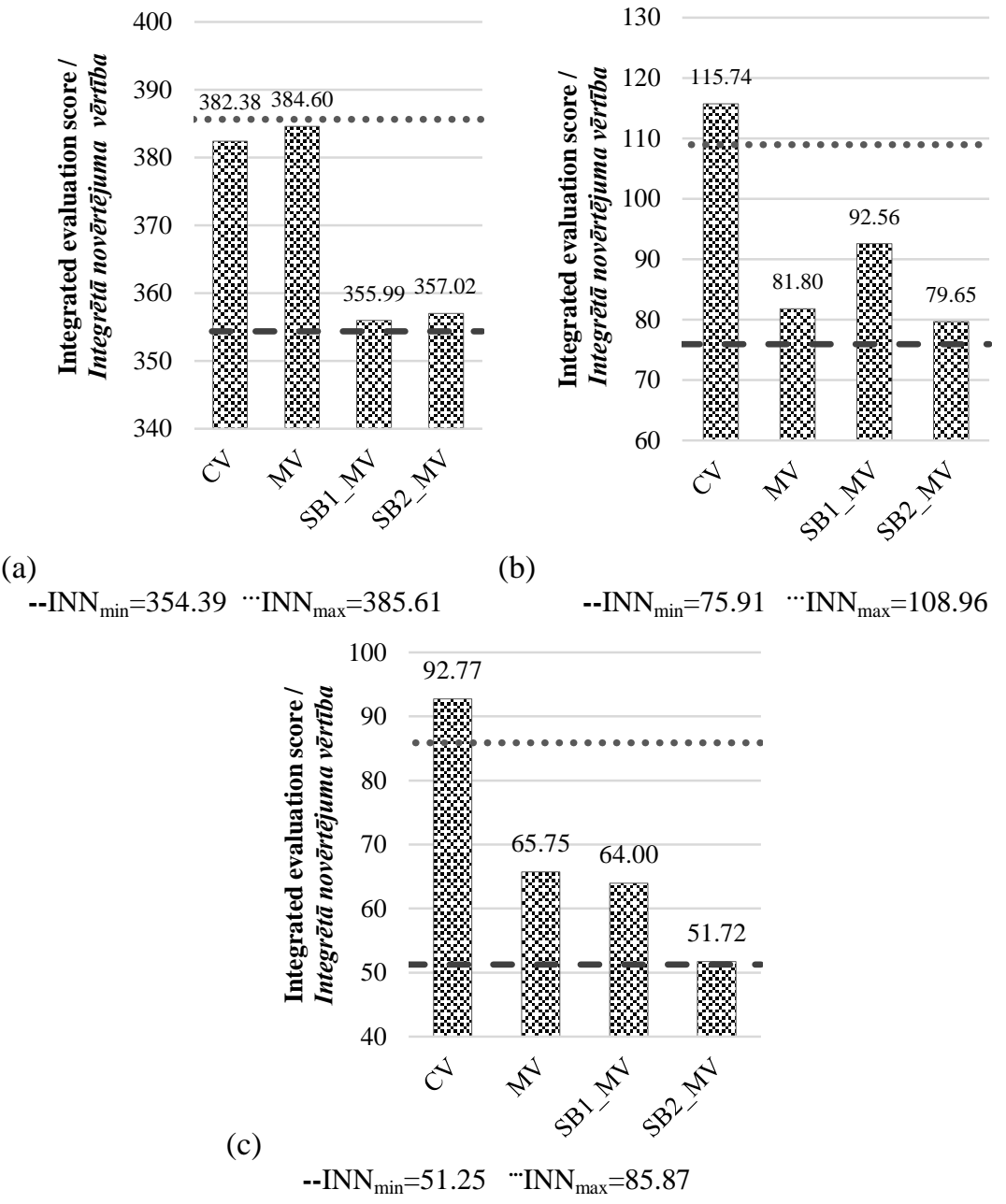

Fig.22 Drying suitability for biological value maintainance in (a) dills, (b) parsleys and (c) celeries /

22.att. Kaltēšanas piemēerotība, lai saglabātu biologisko vērtību (a) dillēs, (b) pētersīlos un (c) selerijās

3.0 min steam-blanching followed by MV drying and MV drying of parsleys (Fig.22 b) had the lowest integrated value and was most suitable method for obtaining dried parsleys with highest biological value. $3.0 \mathrm{~min}$ 
steam-blanching followed by MV drying of celeries (Fig.22 c) had the lowest integrated value and was most suitable method for obtaining dried celeries with highest biological value.

The integrated evaluation shows that MV drying (Fig.23 a) of celery roots had lowest integrated value and was the best drying method for obtaining celery roots with highest nutritional and biological composition. 3.0 min steamblanching followed by MV drying has shown the lowest integrated value (Fig.3.23 b) of carrots and was the best drying method for obtaining dried carrots with highest nutritional and biological composition.

120

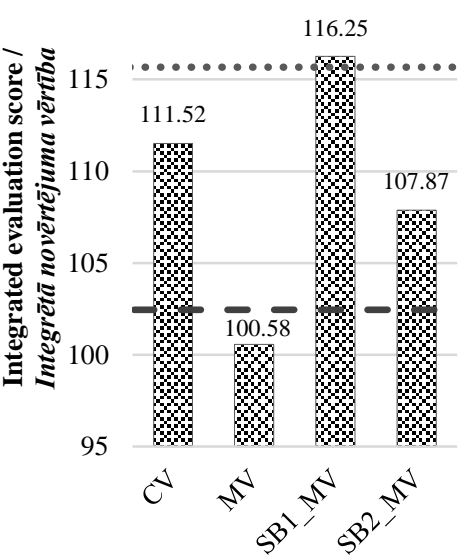

(a)

--INN $\mathrm{INin}_{\min }=102.44 \quad \cdots \mathrm{INN}_{\max }=115.66$
105

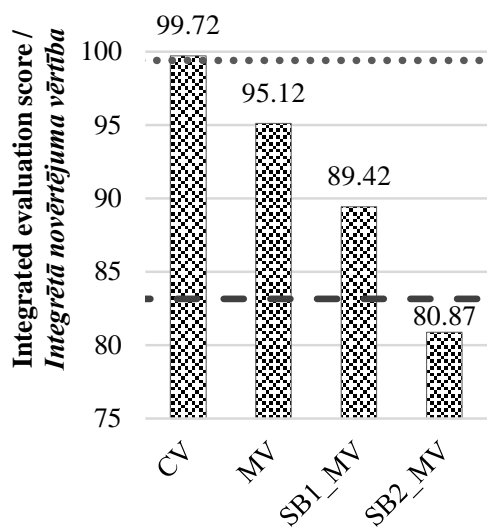

(b)

Fig.23 Drying suitability for biological value maintainance in (a) celery roots and (b) carrots /

23.att. Kaltēšanas piemērotība biologiskās vērtības saglabāšanai (a) seleriju saknēs un (b) burkānos

The integrated evaluation shows that 3.0 min steam-blanching followed by MV drying (Fig.24 a) of leeks had lowest integrated value and was the best drying method for obtaining dried leeks with highest nutritional and biological composition. Convective dried onions shows the lowest integrated value (Fig.24 b) and was the best drying method for obtaining product with highest biological value. Microwave-vacuum drying is most suitable drying technique and shows lowest integrated value (Fig.24 c) to obtain dried garlics with highest biological value. 

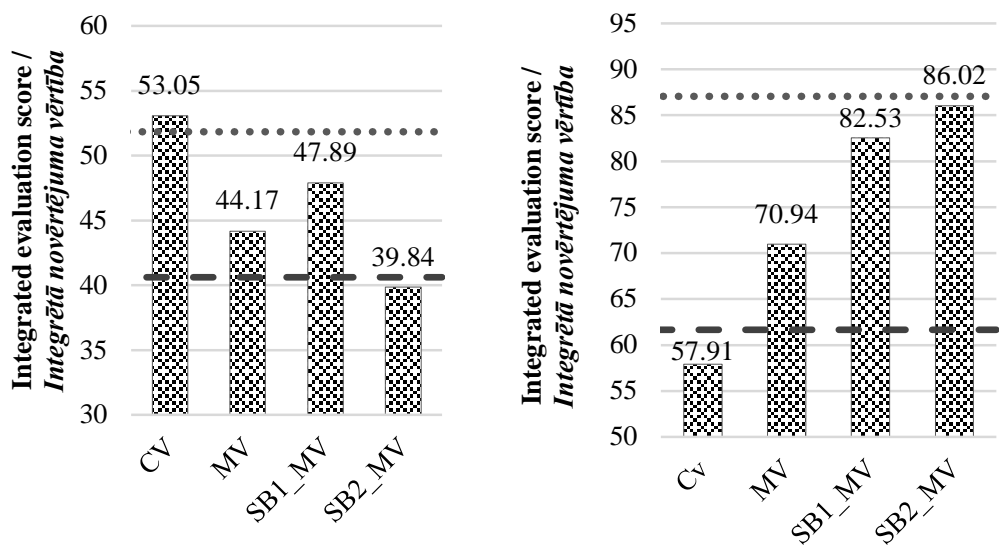

(a)

(b)

$$
\begin{array}{lll}
-\mathrm{INN}_{\min }=40.63 & \cdots \mathrm{INN}_{\max }=51.85 \quad--\mathrm{INN}_{\min }=61.64 & \cdots \mathrm{INN}_{\max }=87.06
\end{array}
$$

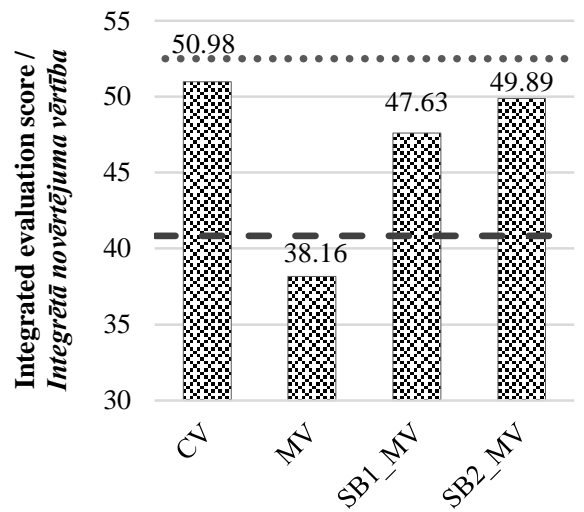

(c)

$$
--\mathrm{INN}_{\min }=40.83 \quad \cdots \mathrm{INN}_{\max }=52.50
$$

Fig.24 Drying suitability for biological value maintainance in (a) leeks, (b) onions and (c) garlics /

24 att. Kaltēšanas piemēerotība bioloğiskās vēertības saglabāšanai (a) puravos, (b) sīpolos un (c) ķiplokos

\section{CONCLUSIONS}

1. Moisture content in all analysed Apiaceae spices was lower than $10 \%$, using convective and microwave-vacuum drying methods. Pre-processing with steam did not affect the total colour difference $(\Delta \mathrm{E}<10)$ compared to fresh spices. Colour changes of dried spices were noticeable $(\Delta \mathrm{E}>23)$ and a significantly higher total colour difference was observed in convective dried parsleys $(\mathrm{p}<0.05)$. 
2. The content of carotenoids significantly increased in dills and celeries after conventional and microwave-vacuum drying $(\mathrm{p}<0.05)$. It is possible to increase the carotenoid content in microwave-vacuum dried parsleys and celeries using pre-processing. Eleven organic acids were determined in Apiaceae spices and the amount changed significantly with the processing methods used; the highest ascorbic acid changes were observed in samples dried in convective dryer.

3. Spices dried in microwave-vacuum dryer with steam-blanching pretreatment had a significant increase of total phenolics, flavonoids and phenolic acids, and the antiradical activity was higher, respectively. Principal component analysis showed that main phenolics in dills are rutin, 4-hydroxybenzoic acids, 3.4-dihydroxybenzoic acid, 3.5dihydroxybenzoic acid and luteolin; in parsleys- 3-hydroxycinnamic acid, rutin, catechin, sinapic acid, chlorogenic acid, quercetin and luteolin; while in celeries- 2-hydroxycinnamic acid, 4-hydroxybenzoic acid, luteolin, quercetin, sinapic acid, rutin and catechin, and their concentrations changed depending on the of type of processing.

4. Apiaceae vegetables had similar trend to Apiaceae spices - the moisture content in vegetables was lower than $10 \%$ after convective and microwave-vacuum drying, while the total colour difference $\Delta \mathrm{E}$ was higher than 25 units. Less severe colour changes were observed in microwave-vacuum dried vegetables with 3.0 min steam-blanching.

5. Carotenoid content significantly decreased in celery roots and carrots after convective and MV drying ( $\mathrm{p}<0.05)$. microwave-vacuum dried carrots had a significantly higher carotenoid content, compared to carrots dried in convective dryer. Steam-blanching pre-processing significantly decreased the content of carotenoids in Apiaceae vegetables. Total organic acid content in celery roots decreased after drying and pre-processing, while it varied in carrots. Ascorbic acid content in both Apiaceae vegetables decreased after all the types of processing.

6. A significant increase of phenolics, flavonoids and phenolic acids was observed in vegetables which were processed in microwave-vacuum dryer after steam-blanching; these samples also had a higher antiradical activity. Total phenolic, flavonoid and phenolic acid content in Apiaceae vegetables was lower than in Apiaceae spices. Steam-blanching followed by microwave-vacuum drying increased the content of phenolics but decreased flavonoid and phenolic acid content in celery roots and carrots. The highest antiradical activity was determined in microwave-vacuum dried vegetables with steam-blanching pre-processing using both ABTS and DPPH methods. 
7. Principal component analysis showed that the main phenolics in celery roots were catechin, rutin, gallic acid, 3.4-dihydroxybenzoic acid, 4hydroxybenzoic acid, sinapic acid, 2-hydroxycinnamic acid and 3hydroxycinnamic acid, whereas in carrots- 3.4-dihydroxybenzoic acid, 3.5-dihydroxybenzoic acid, sinapic acid, catechin and kaempferol.

8. The moisture content in Allium spices was lower than $10 \%$ with both drying methods. Significant colour changes were observed in both drying processes- in convective and microwave-vacuum dried spices.

9. Total carotenoid content of dried Allium spices was significantly affected by steam-blanching and the content increased in leeks, while it decreased in onions and garlics. Organic acid content, including ascorbic acid, changed as a result of all the processing methods.

10. Total phenolic content changed minimally with steam-blanching, but significantly increased in convective dried Allium spices. Opposite situation was observed for total flavonoid and phenolic acid content, resulting in decrease after drying. Increased phenolic content in Allium spices lead to increased antiradical activity.

11. Principal component analysis showed that the main phenolics in leeks are catechin, rutin, luteolin, gallic acid, 3.4-dihydroxybenzoic acid, chlorogenic acid, sinapic acid and 2-hydroxycinnamic acid; in onions gallic acid, t-ferulic acid, rutin and quercetin; and in garlics catechin, 4hydroxybenzoic acid, syringic acid, vanillin, t-ferulic acid, 3hydroxycinnamic acid and kaempferol.

12. Integrated evaluation showed that convective drying is the most appropriate drying method for onions, while microwave-vacuum drying for garlics and celery roots, in order to obtain the dried product with the highest biological value. Steam-blanching for $1.5 \mathrm{~min}$ followed by microwave-vacuum drying is the most suitable method for dills, whereas for leeks, carrots, parsleys and celeries the most suitable method is steamblanching for $3.0 \mathrm{~min}$ followed by microwave-vacuum drying.

13. The proposed hypothesis is confirmed: it is possible to maximally maintain biologically active compounds of vegetables and spices using microwave-vacuum drying. 


\section{PĒTİJUMA AKTUALITĀTE}

Veselīga uztura svarīga sastāvdaļa ir dārzeṇi un garšaugi. Tie satur vitamīnus, diētiskās šķiedrvielas, cukurus, organiskās skābes, mikro - un makro - elementus, un bioloǵiski aktīvos savienojumus. To realizācijas laiks ir samērā 1̄ss, jo ir ar augstu mitruma saturu (Patras et al., 2011; Hossain et al., 2011). Dārzeṇi un garšaugi ir sezonāli produkti, un tāpēc ir nepieciešams atrast apstrādes metodes uzglabāšanas laika pagarināšanai, saglabājot to biologisko vērtību. Dažādi faktori ietekmēe produktu sastāvdaļas, īpaši bioloǵiskos savienojumus, kāa, piemēram, audzēšanas apstākḷi, temperatūra, gaismas intensitāte, un ūdens pieejamība augšanas laikā un ievākšanas laiks (AlarconFlores et al., 2015). Viena no visbiežāk lietotajām metodēm produkta realizācijas laika pagarināšanai ir kaltēšana. Pielietojot augstākas temperatūras pārtikas produktiem, tas var būtiski ietekmēt to kvalitāti, kas var novest pie uztura komponentu noārdīšanās (Garcia-Parra et al., 2016). Kaltēšanas temperatūrām vēlams būtu robežās starp $45^{\circ} \mathrm{C}$ un $60^{\circ} \mathrm{C}$, lai samazinātu gaistošo un bioloǵiski aktīvo savienojumu noārdīšanos un krāsu izmaiņas produktā (Schweiggert et al., 2007). Kaltēšana augstākās temperatūrās var veicināt fenolu savienojumu noārdīšanos un ietekmēt antioksidantu un brīvo radikāḷu saistī̌sanas aktivitāti (Vashisth et al., 2011).

Viena no visbiežāk pētītajām kaltēšanas metodēm ir konvekcijas tipa kaltēšana, kur tiek pielietotas dažādas temperatūras uzturvērtības saglabāšanai, tomēr kaltēšanas laiki var atšksirties no pāris stundām līdz dažām dienām atkarībā no izvēlētā temperatūras režīma. Pēdējos gados mikroviḷnu-vakuuma (MV) kaltēšanas process ir ieguvis atpazīstamību kā savādāka un sekmīga kaltēšanas metode. Kaltēšanas procesā ir iespējams nodrošināt temperatūru, kas ir zemāka nekā $40 \pm 1{ }^{\circ} \mathrm{C}$. Procesa ilgums samazinās, salīdzinot ar konvekcijas tipa kaltēšanu tādā pašā temperatūrā (līdz dažām stundām) un tieša skābekḷa iedarbība ir limitēta kaltēšanas laikā. Rezultātā ir iespējams prognozēt, ka, kaltējot dārzeņu un garšaugus mikroviḷnu-vakuuma kaltē, ir iespējams maksimāli saglabāt to biolog̣iski aktīvos savienojumus, jo samazinātā skābekḷa piekḷuve limitē oksidēšanās procesus produktā.

Saskaņā ar EU regulu 2015/2283, mikrovilı̣nu-vakuuma kaltēšanas process definēts kā jauns netermisks process.

Tāpēc pētījumi ir nepieciešami, lai izvērtētu kvalitātes parametrus un iespējamību saglabāt biologisko vērtību mikroviḷnu-vakuuma kaltētiem dārzeņiem un garšaugiem, salīdzinot tos ar konvekcijas tipa kaltē kaltētiem paraugiem.

Promocijas darba hipotēze: kaltējot dārzeņus un garšaugus mikroviḷnuvakuuma kaltē ir iespējams tajos maksimāli saglabāt biologiski aktīvos savienojumus.

Promocijas darba hipotēzi pierāda ar šādām aizstāvamām tēzēm: 
1. pētīt ķīmisko un fizikālo parametru izmaiņas Apiaceae garšaugos (dillēs, pētersī̄os, selerijās) pēc tvaicēšanas apstrādes un kaltēšanas procesiem;

2. analizēt k̦īmisko un fizikālo parametru izmaiņas Apiaceae dārzeṇos (seleriju saknēs, burkānos) pēc tvaicēšanas apstrādes un kaltēšanas procesiem;

3. noteikt ķīmisko un fizikālo parametru izmaiņas Allium garšaugos (puravos, sīpolos, ķiplokos) pēc tvaicēšanas apstrādes un kaltēšanas procesiem;

4. veikt integrēto novērtējumu kaltētiem dārzeņiem un garšaugiem, lai novērtētu piemērotāko kaltēšanas metodi biolog̣iskās vērtības saglabāšanai.

Promocijas darba pētîjuma objekts: Latvijā audzēti dārzeņi un garšaugi

Promocijas darba mērķis ir izvērtēt kaltētu dārzeņu un garšaugu kvalitātes parametrus un biologiskās vērtības izmaiņas, izmantojot paraugu pirmapstrādi ar tvaiku un to kaltēšanu mikrovilı̧u-vakuuma kaltē, salīdzinot tās ar svaigiem un konvekcijas tipa kaltē kaltētiem paraugiem.

Darba mērksa sasniegšanai izvirzīti šãdi uzdevumi:

1. pētìt ķīmisko un fizikālo parametru izmaiņas Apiaceae garšaugos (dillēs, pētersīlos, selerijās) pēc tvaicēšanas apstrādes un kaltēšanas procesiem;

2. analizēt k̦īmisko un fizikālo parametru izmaiṇas Apiaceae dārzeṇos (seleriju saknēs, burkānos) pēc tvaicēšanas apstrādes un kaltěšanas procesiem;

3. noteikt ķīmisko un fizikālo parametru izmaiņas Allium garšaugos (puravos, sīpolos, ķiplokos) pēc tvaicēšanas apstrādes un kaltēšanas procesiem;

4. veikt integrēto novērtējumu kaltētiem dārzeņiem un garšaugiem, lai novērtētu piemērotāko kaltēšanas metodi bioloǵiskās vērtības saglabāšanai.

Promocijas darba novitāte un zinātniskais nozīmīgums:

1. Izvērtēti ar tvaiku apstrādāti un divu dažādu kaltēšanas procesu ietekme uz biolog̣iski aktīvajiem savienojumiem Latvijā audzētiem dārzeņiem un garšaugiem;

2. Izmantojot integrēto novērtējumu kaltētiem dārzeņiem un garšaugiem, ir noteikta piemērotākā kaltēšanas metode katram dārzenim un garšaugam, kurā vislabāk saglabājas produkta biologiiskā vērtība.

Promocijas darba tautsaimnieciskā nozīmība:

1. Izmantojot pirmapstrādi ar tvaiku un mikrovilı̧nu-vakuuma kalti, ir iespējams ražošanā zemākās kaltēšanas temperatūrās un īsākā laikā iegūt kaltētus dārzeņus un garšaugus, saglabājot iegūtā produkta biologiisko vērtību.

\section{ZINĀTNISKĀ DARBA APROBĀCIJA}

Pētījuma rezultāti ir apkopoti 9 publikācijās un 7 anotāciju grāmatās

Par rezultātiem ziņots 15 starptautiskās zinātniskajās un praktiskajās konferencēs, simpozijos, samitos un kongresos Bulgārijā, Čehijā, Vācijā, İrijāa, Latvijā, Lietuvā, Krievijā un Zviedrijā. 


\section{MATERIĀLI UN METODES}

\section{Pētījuma laiks un vieta}

Pētījumi veikti laikā no 2012. līdz 2015. gadam. Paraugi izstrādāti un analīzes veiktas Latvijas Lauksaimniecības universitātes Pārtikas Tehnologijas fakultātes laboratorijās.

\section{Pētījumā izmantotie materiāli}

Pētījuma veikšanai ir izvēlēti 8 dārzeņi un garšaugi, un tie grupēti pēc dzimtām (1.tabula). Paraugu apzīmējumi pēc apstrādes veidi ir parādīti 2.tabulā.

\section{Pētījuma struktūra}

Pētījums veikts četros posmos (1.att.) un pētījuma tehnologiskā shēma dota 2.attēlā.

\section{I posms - Svaigi dārzeņi un garšaugi}

Pētījumā izmantoti Latvijā, Zemgales reǵionā audzēti 8 dārzeņi un garšaugi (dilles, pētersīịi, selerijas, puravi, sīpoli, ķiploki, seleriju saknes, burkāni), kas ievākti tehniskās gatavības stadijā (no septembra līdz oktobra sākumam). Paraugu fizikālie un ķīmiskie parametri tika analizēti tūlīt pēc ievākšanas.

\section{II posms - Dārzeṇi un garšaugi, kas kaltēti konvekcijas un mikroviḷnu- vakuuma kaltēe}

Iepriekš minētie dārzeņi un garšaugi tika sagatavoti kaltēšanai - seleriju saknes, burkāni, puravi, sīpoli un ķiploki tika sagriezti 3 līdz $3.5 \mathrm{~mm}$ šķēēès, bet dilles, pētersīịi un seleriju lapas tika kaltētas bez kātiniem (tikai lapas-zaļā masa). Katrai kaltēšanai tika izmantoti $3 \mathrm{līdz} 3.5 \mathrm{~kg}$ iepriekš minēto dārzeṇu un garšaugu. Pēc kaltēšanas noteica katram dārzenim un garšaugam paredzētos fizikālos un ķīmiskos rādītājus.

\section{III posms - Pirmapstrādes ar tvaiku ietekme uz MV kaltētiem dārzeṇiem un garšaugiem}

Pirmapstrāde ar tvaiku tika izmantota, lai noteiktu, vai var uzlabot mikrovl̦nu-vakuuma kaltē kaltētu dārzeņu un garšaugu fizikālos un ķīmiskos parametrus. Paraugi tvaika apstrādei tika pagatavoti līdzīgi kā kaltēšanas procesam. Tie tika tvaicēti 1.5 un 3.0 minūtes kameras tipa tvaika katlā (Tefal, Vitamin+, K̦īna), kas aizvērts ar vāku. Paraugu apstrāde notika virs vāroša ūdens $\left(95 \pm 1^{\circ} \mathrm{C}\right)$ vienā slānī. Pēc apstrādes ar tvaiku paraugus ievietoja polietilēna maisā un dzesēja ledus aukstā ūdenī, lai nodrošinātu straujāku dzesēšanas procesu. Ar tvaiku apstrādātos paraugus analizēja un tālāk kaltēja MV kaltē. Iegūtajiem kaltētajiem paraugiem ar pirmapstrādi veic fizikālo un ķīmisko parametru analīzi.

\section{IV posms - Kaltētu dārzeṇu un garšaugu integrētais novērtējums}

Kaltētiem dārzeņiem un garšaugiem veikts integrētais novērtējums, lai noteiktu piemērotāko kaltēšanas procesu bioloǵiskās vērtības saglabāšanai. 


\section{Pētījumā izmantotās metodes}

Metodes, kas izmantotas fizikālo un ķīmisko parametru noteikšanai, apkopotas 3. tabulā.

\section{Datu matemātiskā apstrāde}

Iegūto datu apstrāde veikta, izmantojot Microsoft Excel for Windows 10.0 un XLSTAT 2016 paketi. Iegūtajiem rezultātiem aprēķināta vidējā aritmētiskā vērtība un standartnovirze. Datu interpretācijai veikta vienfaktora un divfaktoru dispersijas analīze (ANOVA), korelācijas analīze, kā arī izmantots rīks Principal Component analysis (galveno komponentu analīze) (PCA). Galveno komponentu analīze (PCA) tika veikta, lai skaidrotu sakarības starp parauga apstrādes veidu un organisko skābju un fenolu savienojumu sadalījumu. Atšķirības starp vērtībām uzskatītas par būtiskām, ja $p \leq 0.05$. Pīrsona korelācijas koeficients aprēķināts, lai novērtētu sakarības starp rezultātiem. Kaltētu dārzeņu un garšaugu novērtēšanai pēc ķīmiskajiem un fizikālajiem parametriem veikts integrētais novērtējumus.

\section{REZULTĀTI UN DISKUSIJA}

\section{Fizikālo un ķīmisko parametru atšķirības Apiaceae garšaugos (dilles, pētersīli,i, selerijas)}

Mitrums saturs svaigos garšaugos bija: dillēs - $84.64 \pm 0.85 \%$, selerijās $80.62 \pm 0.81 \%$ un pētersī̄os - $78.98 \pm 0.79 \%$. Apstrādājot svaigos paraugus ar tvaiku, mitruma saturs izmainījās minimāli. Kaltējot paraugus konvekcijas tipa un MV kaltēs, mitruma saturs pētāmos garšaugos bija zemāks nekā 10\%. Krāsu atškirīības ar tvaiku apstrādātām un kaltētām dillēm, pētersīḷiem un selerijām vizuāli neatšķ̄īās no svaigajiem $(\Delta \mathrm{E}<10)$, bet kaltējot tika novērotas būtiskas izmainas $(. \Delta \mathrm{E}>23)$. İpaši ievērojamas krāsu izmaiņas bija konvekcijas tipa kaltē kaltētiem pētersīl liem. $(\mathrm{p}<0.05)$.

Garšaugos karotinoīdi ir vieni no galvenajiem antioksidantiem. Dillēs, pētersīlos un selerijās kopējais karotinoīdu daudzums variē robežās no $278.67 \pm 16.64$ (selerijas) līdz 469.00 $\pm 13.83 \mathrm{mg} \beta$-CE $100 \mathrm{~g}^{-1} \mathrm{DW}$ (dilles). Garšaugu apstrādes procesi dažādi ietekmēja karotinō̄du saturu (3.att.)

Dillıu apstrāde ar tvaiku (1.5 min) nedaudz izmainīja to saturu, bet pēc 3.0 min apstrādes ar tvaiku karotinoīdu saturs būtiski palielinājās. Karotinoīdu saturs pētersīḷos mazliet palielinājās pēc apstrādes ar tvaiku. Selerijās karotinoīdu saturs palielinājās, izmantojot apstrādi ar tvaiku. Apstrādātos paraugus, kaltējot MV kaltē, kopējais karotinoīdu daudzums būtiski palielinājās, salīdzinot ar svaigām selerijām. To saturs palielinās arī vairāk, nekā izmantojot konvekcijas tipa kaltēšanu.

Organiskās skābes, kas tika noteiktas svaigās un kaltētās dillēs, bija skābeņskābe, askorbīnskābe, citronskābe, dzintarskābe, salicilskābe un benzoskābe dažādās koncentrācijās (4.tabula) Vislielākās izmainas novērotas askorbīnskābei paraugos, kas kaltēti konvekcijas kaltē. 
Skābeņskābe dillēs samazinās pēc apstrādes ar tvaiku, bet, tās kaltējot konvekcijas tipa un MV kaltē, skābeņskābes saturs paaugstinās. Hinīnskābe dillēs tika noteikta augstās koncentrācijās, un pēc īsa laika apstrādes ar tvaiku saturs būtiski samazinās, un pēc ilgākas apstrādes skābe netika konstatēta. Ābolskābe svaigās dillēs bija augstās koncentrācijās. Apstrāde ar tvaiku un kaltēšana būtiski samazina tās saturu. Malonskābe netika konstatēta svaigā paraugā, un, apstrādājot dilles, skābes saturs būtiski palielinās. Citronskābes saturs būtiski samazinās dillēs, kas apstrādātas ar tvaiku, bet kaltēšana būtiski paaugstina saturu. Dzintarskābe tika noteikta zemākās koncentrācijās, un apstrāde ar tvaiku minimāli samazināja skābi. Dzintarskābes saturs būtiski palielinājās pēc kaltēšanas.

Salicilskābe dillēs palielinājās pēc apstrādes ar tvaiku, un visaugstākis pieaugums novērots konvencionāli kaltētās dillēs, bet MV kaltētās dillēs skābe samazinājās un pirmasptrāde samazināja saturu vairāk. Benzoskābes un salicilskābes pieaugums var būt skaidrojams ar ķīmiskajiem procesiem apstrādes rezultātā. Augos esošā benzoskābe var pārveidoties vai konvertēties hidroksilācijas procesā par citu hidroksibenzoskābes formu (hidroksilācijas reakcija) (Widhalm \& Dudareva, 2015).

Svaigos un kaltētos pētersīḷos skābeņskābe, hinīnskābe, malonskābe, askorbīnskābe, citronskābe, dzintarskābe un salicilskābe tika noteiktas dažādās koncentrācijās un to saturs izmainījās (5.tabula). Pētersīḷos skābeņskābe būtiski samazinājās pēc apstrādes ar tvaiku, bet palielinājās konvencionāli kaltētos pētersīḷos. Rezultātus var salīdzināt ar Han et al. (2016) pêtījumu, kur.novēroja, ka skābeņskābe ir termostabila temperatūrās, kas zemākas par $80^{\circ} \mathrm{C}$ un augstākās temperatūrās savienojums sadalās.

Hinīnskābe pētersīḷ os samazinājās pēc apstrādes ar tvaiku, bet, izmantojot konvencionālo un MV kalti, skābes saturs paaugstinājās. Citronskābes saturs pētersīlos pēc konvencionālās kaltēšanas palielinājās, bet ar MV kaltēšanu samazinājās. Dzintarskābe pētersīḷos būtiski samazinājās pēc apstrādes ar tvaiku, un pozitīvs efekts tika novērots kaltētos pētersīḷos. Kopējais organisko skābju saturs samazinājās pētersīḷos, tos apstrādājot ar tvaiku, bet konvencionālās kaltēšanas rezultātā kopējais skābes saturs būtiski paaugstinājās ar paaugstināto skābeņskābes, malonskābes un citronskābes saturu.

Selerijās galvenās organiskās skābes bija skābeņskābe, askorbīnskābe, citronskābe un salicilskābe, un benzoskābe. Apstrādes procesā to saturs mainījās (6.tabula). Selerijās skābeņskābe samazinājās pēc apstrādes ar tvaiku un tās kaltējot MV kaltē, un pirmapstrāde ar tvaiku un kaltēšana MV kaltē norādīja pieaugumu, salīdzinot ar MV kaltētu seleriju saturu. Iespējams, ka ilgstoša termiskā apstrāde un spiediens, kā arī enerğija no MV kaltes stimulē oksidēšanas procesus. Temperatūra, spiediens un augstas frekvences amplitūdas kombinācija palīdz noārdīt skābeņskābi. Labāka degradācija tika novērota palielinot MV kaltes jaudu (Dukkanci \& Gunduz, 2006). Hinīnskābe selerijās samazinājās, un tika novērota līdzịga degradācijas pakāpe kā skābeņskābei apstrādātos ar tvaiku un konvencionāli kaltētos paraugos. 
Selerijās citronskābe samazinājās pēc apstrādes ar tvaiku, ilgāka apstrāde samazināja tās saturu vairāk. Konvencionāli kaltētos selerijas paraugos tika atrasta līdzīga citronskābes koncentrācija kā MV kaltē kaltētos paraugos. Benzoskābe tika noteikta zemākās koncentrācijas un apstrāde ar tvaiku, un konvekcijas kaltēšana samazināja skābes saturu vairāk nekā MV kaltētās selerijās.

Ābolskābe daudzums samazinājās apstrādātās selerijās. Ābolskābe dekarboksilējas vairākos posmos, un fotodegradācijas rezultātā veidojas malonskābe un citi gala produkti (Irawaty et al., 2011).

Fenolu savienojumi (kopējie fenoli, flavonoīdi un fenolskābes) garšaugos tika atrasti dažādās koncentrācijās, kas izmainījās, tos kaltējot un apstrādājot ar tvaiku. Pēc kaltěšanas fenolu saturs būtiski palielinājās.Visvairāk to bija kaltētās dillēs. Pirmapstrade ar tvaiku uzlaboja kopējo fenolu saturu MV kaltētos Apiaceae garšaugos. $3.0 \mathrm{~min}$ apstrāde ar tvaiku un MV kaltēšana palielināja to saturu vairāk dillēs un pētersīḷos (4.att.).

Paaugstinātu kopējo fenolu daudzumu paraugos var skaidrot ar to, ka daži savienojumi kā, piemēram, askorbīnskābe, var oksidēt Folina-Ciocalteu reaǵentu, ko izmanto kopējo fenolu satura noteikšanai. (Zhang \& Hamauzu, 2004).

Sakņu dārzeņos vienkāršie fenoli ir visvairāk izplatīti, bet lapu dārzeņos biežāk noteikti flavonu glikozīdi un flavonoli. Pētersīḷos, selerijās, brokoḷos un garšvielās biežāk sastopamie fenoli ir flavonu aglikoni un flavonoli (Sakakibara et al., 2003). Fenolu sastāvs svaigos un apstrādātos augos mainās dažādu faktoru ietekmē, kā, temperatūra un skābekḷa klātbūtne procesa laikā.

Galveno komponentu analīze norāda, ka dillēs galvenie fenolu savienojumi ir rutīns, 4-hidroksibenzoskābe, 3.4-dihidroksibenzoskābe, 3.5dihidroksibenzoskābe un luteolīns, pētersīḷlos - 3-hidroksikanēlskābe, rutīns, katehīns, sinapīnskābe, hlorogēnskābe, kvercetīns un luteolīns, savukārt selerijās - 2-hidroksikanēlsksābe, 4-hidroksibenzoskābe, luteolīns, kvercetīns, sinapīnskābe, rutīns un katehīns, kuru koncentrācija mainījās atkarībā no apstrādes veidiem. (6.,7. un 8.att)

Antiradikālo aktivitāti iespējams noteikt ar dažādā spektrofotometriskām metodēm. Visbiežāk tiek lietotas DPPH un ABTS metodes. Ar abām radikāļu metodēm Apiaceae garšaugu antiradikālā aktivitāte bija augsta (8.att.). Garšaugos aktivitāte palielinās, ja palielinās kopējo fenolu savienojumu saturs visos paraugos pēc apstrādes ar tvaiku un kaltēšanas.

Antioksidantu kapacitāte augos var mainīties pēc produkta ievākšanas atkarībā no apstrādes veida un uzglabāšanas apstākḷiem (Jimenez-Zamora et al., 2016). 


\section{Fizikālo un ķīmisko parametru atšķirības Apiaceae dārzeṇos (seleriju saknes, burkāni)}

Seleriju saknēs mitruma saturs bija $88.95 \pm 0.89 \%$ un burkānos $89.78 \pm 0.90 \%$. Dārzeņu apstrāde ar tvaiku minimāli izmainīja mitruma saturu un kaltējot konvekcijas un MV kaltē mitrums tika samazināts mazāk kā 10\%.

Vizuālas krāsu izmaiņas tika novērotas paraugos, kuri ilgāk apstrādāti ar tvaiku. Būtiski augstākas krāsu izmaiņas vērojamas konvencionāli kaltētos burkānos un MV kaltē kaltētās seleriju saknēs. Apstrāde ar tvaiku un MV kaltēšana saglabā krāsu abiem paraugiem. Brūnēšana augliem vairākumā gadījumu ir saistîta ar endogēno fenolu enzimātisko oksidēšanos, kuri vēlāk polimerizējas, veidojot brūnus produktus (Nunez-Mancilla et al., 2013).

Kopējais karotinoīdu saturs Apiaceae dārzeņos variē plašās robežās, un seleriju saknēs tika noteikts zemākā koncentrācijā kā burkānos. Neliels pieaugums novērojams burkānos, kas apstrādāti ar tvaiku 1.5 min, bet ilgāka apstrāde ar tvaiku samazināja karotinoīdu saturu. Augstākais pieaugums vērojams MV kaltētos burkānos (9.att).

Augu šūnās karotinoīdi eksistē cis un trans formās. Apstrādes rezultātā daļa trans formas var degradēties vai pārvērsties / konvertēties par cis formu un to atvasinājumiem, un kopējais karotinoīdu saturs pieaug (Sharma et al., 2012).

Karotinoīdu satura samazināšanās ir saistīta ar oksidēšanos, kas cieši saistīta ar skābekla pieejamību procesa laikā, un temperatūra un gaisma paātrina šo procesu. Šis process ir tieši saistīts ar pigmentu samazināšanu (Murador et al., 2014).

Galvenās organiskās skābes, kas seleriju saknēs noteiktas augstākajās koncentrācijās, bija malonskābe, citronskābe, dzintarskābe, skābeņskābe, vīnskābe, hinīnskābe un askorbīnskābe. To saturs būtiski izmainās kaltējot un apstrādājot ar tvaiku (8.tabula).

Hinīnskābes būtisks pieaugums novērojams ar tvaiku apstrādātās un ar tai sekojošu kaltēšanu MV kaltē kaltētās seleriju saknēs. Hinīnskābes saturs seleriju saknēs samazinās pēc īsākas apstrādes ar tvaiku vairāk nekā pēc garākas apstrādes ar tvaiku. Konvekcijas kaltē kaltētas seleriju saknes satur augstāku skābeņskābes koncentrāciju kā MV kaltē kaltētas seleriju saknes.

Fumārskābe seleriju saknēs bija noteikta zemās koncentrācijas un apstrāde būtiski ietekmēja to saturu. Īsa laika apstrāde ar tvaiku un kaltēšana būtiski paaugstināja fumārskābes saturu.

Dzintarskābe seleriju saknēs degradējās pēc apstrādes. Apstrāde ar tvaiku un MV kaltēšana būtiski samazināja skābes koncentrāciju, un mazāk samazinājās konvencionāli kaltētās seleriju saknēs. Skābes šķīīiba paaugstinās paaugstinātās temperatūrās un paaugstinoties Gibsa enerǵijai (Mahali et al., 2017), tāpēc ir iespējams, ka, samazinoties ūdens aktivitātei kaltētos produktos, skābes degradācija noris lēnāk paraugos, kas apstrādāti ar tvaiku un kaltējot tos MV kaltē. 
Burkānos galvenās organiskās skābes bija skābeņskābe, vīnskābe un fumārskābe dažādās koncentrācijas un pēc kaltēšanas mainījās (9.tabula).

Skābeñskābes saturs burkānos pēc apstrādes ar tvaiku būtiski samazinājās, un pēc kaltēšanas pieauga. Skābeņskābes saturs minimāli mainījās MV kaltētos burkānos, un pirmapstrāde ar tvaiku un MV kaltēšana samazināja saturu.

Vīnskābe burkānos samazinājās pēc apstrādes ar tvaiku, un pēc konvencionālās kaltēšanas saturs pieauga. MV kaltētos burkānos skābe netika konstatēta un pirmapstrāde ar tvaiku un sekojošā MV kaltēšana būtiski paaugstina saturu.

Citronskābe samazinājās pēc apstrādes ar tvaiku, un paaugstinājās burkānos pēc konvencionālās un MV kaltēšanas. Askorbīnskābe seleriju saknēs samazinājās pēc apstrādes ar tvaiku un kaltēšanas, un produktos skābes saturs bija līdzīgs. Askorbīnskābe burkānos vislabāk saglabājās pēc apstrādes.

Fruktoze un glikoze pārtikā uzlabo vitamīna $\mathrm{C}$ stabilitāti temperatūras robežās $24-45{ }^{\circ} \mathrm{C}$ un samazinās tās stabilitāte robežās $70-90{ }^{\circ} \mathrm{C}$. Paaugstinātas apstrādes temperatūras samazina ūdens aktivitāti un paaugstina ne-enzimātisko brūnēšanu (Herbig \& Renard, 2017). Ir pierādīts, ka mikrovilı̧nu pielietojums slēgtās sistēmās samazina degradēšanos, tāpēc ka mikrovilụu radiācija samazina pārkaršanas iespējamību un minimizē analītu degradāciju (Biesaga, 2011).

Kopējo fenolu saturs Apiaceae garšaugos variē pēc kaltēšanas, un tos apstrādājot ar tvaiku, un bija zemākās koncentrācijās kā Apiaceae garšaugos (10.att.).

Kopējais fenolu saturs seleriju saknēs bija zemāks nekā lapās. Seleriju saknēs un burkānos apstrāde ar tvaiku minimāli ietekmēja kopējo saturu. Konvekcijas kaltē kaltētos paraugos bija augstākas fenolu koncentrācijas kā MV kaltē. Fenolskābes bija zemākās koncentrācijās kā flavonoīdi, un apstrāde ar tvaiku nedaudz samazināja sākotnējo daudzumu, bet būtiski samazinājās pēc kaltēšanas. Fenolskābes un flavonoīdi saglabājās vairāk MV kaltētos dārzeṇos un pirmapstrāde ar tvaiku palīdz saglabāt savienojumus.

Ir piemērotas vairākas hipotēzes fenolskābju izmaiņām apstrādes laikā: daļēja atdalīšanās no saistītajām formām noved pie šķ̄istošo skābju pieauguma. Šķ̄istošo frakciju samazinājums termiskās degradācijas rezultātā un palielinās saistītās formas, kuras veidojas savstarpēji mijiedabojoties fenolskābēm ar produkta makromolekulām (Zaupa et al., 2015). Termiski apstrādājot produktu var noritēt fenolu polimerizācija vai arī koncentrācijas pieaug pārtikas produktā apstrādes laikā (Tomas et al., 2017).

Galveno komponentu analīze parādīja, ka galvenie fenolu savienojumi seleriju saknēs, kas tika noteikti dažādās koncentrācijās, bija katehīns, rutīns, galluskābe, 3.4-dihidroksibenzoskābe, 4-hidroksibenzoskābe, sinapīnskābe, 2hidroksikanēlsskābe un 3-hidroksikanēlskābe un apstrāde dažādi ietekmēja to koncentrācijas. Burkānos 3.4-dihidroksibenzoskābe, 3.5-dihidroksibenzoskābe, sinapīnskābe, katehīns un kampferols tika noteikti dažādās koncentrācijās un aptrādes rezultātā izmainījās (11., 12. att). 
Antiradikālā aktivitāte Apiaceae dārzeṇos būtiski palielinājās pēc garākas apstrādes ar tvaiku un pēc kaltēšanas ar ABTS metodi, bet, izmantojot DPPH metodi, antiradikālā aktivitāte būtiski palielinājās pēc kaltēšanas (13.att.).

Paaugstināta antiradikālā aktivitāte ar DPPH radikāli svaigos dārzeņos, kam pielietotas dažādas blanšěšanas tehnikas, varētu būt skaidrojamas ar faktu, ka termiskā blanšěšana sagrauj šūnu apvalkus un tādējādi atvieglo antioksidantu atbrīvošanos (Wang et al., 2017).

Galvenie cukuri seleriju saknēs un burkānos tika noteikti, un to koncentrācijas mainījās pēc kaltēšanas. Iegūtie rezultāti tika izmantoti integrētajam novērtējumam.

\section{Fizikālo un ķīmisko parametru atšķirības Allium garšaugos (puravi, sīpoli, ksiploki)}

Svaigiem puraviem mitruma saturs bija $88.20 \pm 0.88 \%$, sīpoliem bija $93.84 \pm 0.94 \%$ un kiplokiem $64.02 \pm 0.64 \%$, un apstrāde ar tvaiku būtiski neietekmēja saturu. Allium garšaugos mitruma saturs pēc kaltēšanas tas bija zemāks nekā 10\%.

Karotinoīdu saturs puravos pēc apstrādes ar tvaiku paaugstinājās, bet, kaltējot konvekcijas kaltē, to saturs minimāli palielinās, un, kaltējot paraugus MV kaltē, karotinoīdu saturs būtiski palielinājās. Apstrādāti ar tvaiku un MV kaltēti puravi satur augstāku karotinoīdu saturu, salīdzinot ar paraugiem bez pirmapstrādes. Sīpolos un ķiplokos karotinoīdu saturs bija zemāks nekā puravos. Turklāt saglabājās tendence tiem paaugstināties, apstrādājot paraugus ar tvaiku, bet kaltēšana kopējo saturu samazināja.

Kopumā apstrāde ar tvaiku būtiski palielina karotinō̄du saturu visos Allium dzimtas garšaugos, bet pēc kaltěšanas MV kaltē karotinoīdu saturs samazinās sīpolos un k̦iplokos (14., 15.att.).

Galvenās organiskās skābes puravos bija skābeņskābe, hinīnskābe, ābolskābe, citroskābe, dzintarskābe un salicilskābe un termiskā un kaltēšanas procesi skābju saturu ietekmē dažādi (10.tabula).

Skābeņskābe būtiski samazinājās puravos ar tvaika apstrādi, savukārt kaltēšana konvekcijas kaltē palielināja sākotnējo skābeņskābes saturu. Kaltējot puravus MV kaltē, skābes saturs izmainījās minimāli, un apstrāde ar tvaiku un kaltēšana MV kaltē skābes saturs pieaug. Hinīnskābe puravos būtiski paaugstinājās, izmantojot visas apstrādes metodes.

Malonskābes saturs puravos bija zems, un apstrāde ar tvaiku samazināja saturu, bet kaltēšana paaugstināja. Arī citronskābe puravos samazinājās pēc apstrādes ar tvaiku un kaltējot. Dzintarskābes saturs puravos minimāli palielinājās izmantojot apstrādi ar tvaiku, un kaltējot sākotnējais dzintarskābes saturs palielinājās. Saliciskābe puravos pieauga pamazām izmantojot tvaika apstrādi un kaltēšanu.

Sīpolos hinīnskābe, skābeņskābe, vīnskābe, ābolskābe, citronskābe, fumārskābe un salicilskābe tika noteikta un to saturs mainās apstrādes rezultātā (11.tabula). 
Konvekcijas kaltē kaltēti sīpoli satur augstāku hinīnskābes saturu nekā MV kaltēti sīpoli. Apstrāde ar tvaiku un MV kaltēšana paaugstina hinīnskābes saturu un bija augstāks nekā MV kaltētos paraugos.

Konvekcijas kaltēšanas rezultātā skābeņskābe mainījās minimāli, bet pēc MV kaltēšanas tās saturs samazinājās. Apstrāde ar tvaiku un kaltēšana MV kaltē būtiski samazina skābebeņskābi sīpolos un ilgāka pirmapstrāde negatīvi ietekmē skābes. Pēc apstrādes MV kaltē vīnskābes saturs sīpolos bija samazinājies, bet pēc kaltēšanas konvekcijas kaltē, un ar tvaiku apstrādātos un MV kaltē kaltētos sīpolos vīnskābe netika konstatēta.

Malonskābe būtiski samazinājās, blanšējot paraugus, turklāt novērojama negatīva tendence malonskābei samazināties pagarinot blanšěšanas laiku. Pēc kaltēšanas konvekcijas kaltē malonsābes saturs būtiski nemainījās, bet apstrāde MV būtiski izmainīja tās saturu sīpolos. Salīdzinot blanšētus paraugus pirms MV kaltēšanas, un paraugus, kam blanšěšana netika veikta, bet kas pēc tam bija kaltēti MV, malonskābes saturs pirmajos bija būtiski lielāks.

Citronskābes daudzums pieauga apstrādes rezultātā, un lielākais pieaugums novērots sīpolu paraugiem, kas apstrādāti ar tvaiku 3.0 min un kaltēti MV kaltē. Iespējams, ka apstrāde un MV kaltēšana degradē citronskābi. Fumārskābe sīpolos tiek degradēta pēc apstrādes ar tvaiku, bet kaltēšana palīdz saglabāt šīs skābes saturu tādā pašā līmenī kā svaigos sīpolos.

Apstrādātos kiplokos vīnskābe, hinīnskābe, ābolskābe, dzintarskābe un salicilskābe būtiski izmainās (12.tabula).

Askorbīnskābes saturs puravos apstrādājot ar tvaiku un kaltēšanas rezultātā mainījās minimāli, bet apstrāde ar tvaiku un MV kaltēšana askorbīnskābes saturu puravos samazināja būtiski. Ar tvaiku apstrādāti sīpoli satur būtiski zemāku askorbīnskābes saturu kā konvencionāli kaltēti sīpoli, taču to saturs bija augstāks, nekā MV kaltē kaltētos sīpolus. Savukārt ķiplokos askorbīnskābes saturs minimāli mainījās pēc blanšēšanas un konvekcijas kaltēšanā tas samazinājās vairāk nekā MV kaltēšanā. Tas sasaucas ar citu autoru pētījumiem, ka ūdenī šķisstošie vitamīni, piemēram, askorbīnskābe blanšěšanas procesā dalıejji oksidējas un ir novērojami skābes zudumi (Roongruangsri \& Bronlund, 2015).

Kopējais fenolu saturs minimāli izmainījās termiskās apstrādes rezultātā. Pēc kaltēšanas to saturs būtiski palielinājās - vislielāko pieaugumu novēroja konvencionāli kaltētos Allium garšaugos. Kopējais fenolskābju un flavonoīdu saturs palielinājās pēc apstrādes ar tvaiku un samazinājās pēc kaltēšanas procesiem (16., 17.att.).

İsa un strauja karsēšana var inaktivēt oksidatīvos enzīmus, kas var palīizēt saglabāt fenola tipa savienojumus (Samoticha et al., 2016). Saskaņā ar Nawirska-Olszanska et al. (2017) izmantojot strūklakas tipa mikroviḷnu kaltēšanu ar 2 enerǵijas līmeņiem (100 un 250 W) būtiski samazinās kopējais fenolu saturs un to antiradikālā aktivitāte. Augsts enerğijas līmenis negatīivi ietekmē fenola tipa savienojumus. 
Galveno komponentu analīze norāda, ka puravos galvenie fenolu savienojumi dažādās koncentrācijās bija katehīns, rutīns, luteolīns, galluskābe, 3.4-dihidroksibenzoskābe, hlorogēnskābe, sinapīnskābe un 2hidroksikanēlskābe un apstrādes rezultātā saturs izmainās. Apstrādātos sīpolos galluskābe, ferulskābe, rutīns, kvercetīns tika noteikas dažādās koncentrācijās un apstrāde būtiski ietekmē to saturu. Galvenie fenolu savienojumi ķiplokos bija katehīns, 4-hidroksibenzoskābe, ceriņskābe, vanilīns, t-ferulskābe, 3hidroksikanēlskābe un kaempferols un apstrāde dažādi ietekmēja to saturu (18., 19., 20.att.).

Antiradikālā aktivitāte būtiski palielinājās kaltētos Allium garšaugos un minimālas izmaiņas novēroja, izmantojot termisko apstrādi (21.att).

\section{Kaltētu dārzeņu un garšaugu integrētais novērtējums}

Izmantojot integrēto novērtējumu un pamatojoties uz iegūtajiem rezultātiem (1., 2., 3., daļa), noteica optimālo kaltēšanas un pirmapstrādes procesu katram dārzenim un garšaugam, lai kaltētais produkts būtu ar visaugstāko biologisko vērtību. Integrētā novērtējuma veikšanai izmantoja pazīmju ieguldījuma koeficientus. Visaugstākie ieguldījuma koeficienti bija fruktozei $\left(\mathrm{g} 100 \mathrm{~g}^{-1}\right)$, glikozei un fenoliem, zemākie- krāsu diferencei. Ja gatavā produkta krāsu uzskata kā kvalitātes rādītāju, tad krāsu parametrus var lietot, lai optimizētu kaltēšanas apstākḷus un samazinātu svarīgāko savienojumu degradāciju (Aral \& Vildan Bese, 2016).

Integrētais novērtējums parādīja, ka dillıu pirmapstrāde ar tvaiku, un ar tai sekojošu mikroviḷnu-vakuuma kaltēšanu ir ar viszemāko integrētā novērtējuma vērtību. Tas nozīmēe, ka tas ir vislabākais kaltēšanas paņēmiens, lai iegūtu kaltētas dilles ar visaugstāko bioloǵisko vērtību (22.att.a). Pētersīịu un seleriju pirmapstrāde ar tvaiku 3 minūtes ar tai sekojošu kaltēšanu mikroviļ̧nu vakuuma kaltē, kas ieguva viszemāko integrēto novērtējuma vērtību, ir vispiemērotākais kaltēšanas paṇēmiens (22.att., b, c), kas l̦auj vislabāk saglabāt to biologisko vērtību.

Lai iegūtu kaltētas seleriju saknes ar augstu biologisko un uzturvērtību, ieteicams izmantot mikroviḷnu kaltěšanas paņēmienu, kas integrētā novērtējumā uzrādīja viszemāko integrētā novērtējuma vērtību (23.att., a). Kaltētu burkānu ieguvei ar augstu biologisko un uzturvērtību, kā parāda integrētais novērtējums, jāizmanto pirmapstrāde ar tvaiku 3 minūtes un jākaltē mikrovilınu vakuuma kaltē (23.att., b).

Līdzịgu rezultātu kā burkāniem ieguva, novērtējot apstrādes procesu, ko izmantoja kaltētu puravu ieguvei (24.att., a). Viszemākā integrētā vērtība bija puravu pirmapstrādei ar tvaiku 3 minūšu garumā ar tai sekojošu kaltēšanu mikrovilı̣nu vakuuma kaltē. Konvektīvo kaltēšanu būtu ieteicams izmantot kaltētu sīpolu ieguvei, jo procesam atbilst vismazākā integrētā novērtējuma vērtība, lai produktā maksimāli saglabātos biologiski aktīvās sastāvdaļas (24.att., b). Ķiploku kaltēšana mikroviḷnu vakuuma kaltē ļauj iegūt kaltētus ķiplokus ar maksimāli saglabātu bioloǵisko vērtību (24.att., c). 


\section{SECINĀJUMI}

1. Izmantojot konvekcijas un mikroviḷnu-vakuuma kaltēšanu, visu pētīto Apiaceae dzimtas garšaugu mitruma saturs bija zemāks par $10 \%$. Pirmapstrāde ar tvaiku neietekmēja garšaugu kopējo krāsu diferenci $(\Delta \mathrm{E}<10)$, salīdzinot ar svaigiem garšaugiem. Kaltētu garšaugu krāsas izmaiņas bija izteiktas $(\Delta \mathrm{E}>23)$ un pētersīḷiem novērota būtiski lielāka kopējā krāsu atšķirība pēc to apstrādes konvekcijas kaltē ( $\mathrm{p}<0.05)$.

2. Karotenoīdu saturs būtiski paaugstinājās dillēs un selerijās pēc konvekcijas un mikroviļnu-vakuuma kaltēšanas $(\mathrm{p}<0.05)$. Izmantojot pirmapstrādi, iespējams paaugstināt karotenoīdu saturu mikrovilı̣nuvakuuma kaltē kaltētos pētersīḷos un selerijās. Apiaceae garšaugos tika noteiktas 11 organiskās skābes, kuru saturs būtiski main̄̄jās izmantoto apstrādes paṇēmienu rezultātā; vislielākās izmaiņas novērotas askorbīnskābei paraugos, kas kaltēti konvekcijas kaltē.

3. Mikroviļ̧nu-vakuuma kaltētiem garšaugiem veicot paraugu apstrādi ar tvaiku, novērots būtisks fenolu, flavonōidu un fenolskābju pieaugums, kā arī attiecīgi augstāka antiradikālā aktivitāte. Galveno komponentu analīze norāda, ka dillēs galvenie fenolu savienojumi ir rutīns, 4hidroksibenzoskābe, 3.4-dihidroksibenzoskābe, 3.5-dihidroksibenzoskābe un luteolīns, pētersị̄los- 3-hidroksikanēḷskābe, rutīns, katehīns, sinapīnskābe, hlorogēnskābe, kvercetīns un luteolīns, savukārt selerijās2-hidroksikanēlsskābe, 4-hidroksibenzoskābe, luteolīns, kvercetīns, sinapinnskābe, rutīns un katehīns, kuru koncentrācija mainījās atkarībā no apstrādes veidiem.

4. Apiaceae dzimtas dārzeņiem novērota līdzīga tendence kā Apiaceae garšaugiem - pēc konvekcijas un mikroviḷnu-vakuuma kaltēšanas dārzeṇu mitruma saturs bija zemāks par 10\%, savukārt kopējā krāsas diference $\Delta \mathrm{E}$ bija lielāka par 25 vien̄̄bām. Mazāk izteiktas krāsas izmaiņas bija vērojamas mikrovilņu-vakuuma kaltē kaltētiem dārzeņiem ar $3.0 \mathrm{~min}$ tvaika pirmapstrādi.

5. Karotenōidu saturs būtiski samazinājās seleriju saknēs un burkānos pēc

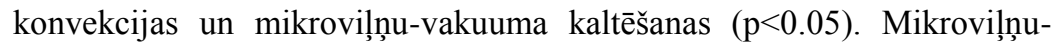
vakuuma kaltē kaltētiem burkāniem bija ievērojami lielāks karotīnu saturs, salīdzinot burkāniem, kas kaltēti konvekcijas kaltē. Pirmapstrāde ar tvaiku būtiski samazināja karotenoīdu saturu Apiaceae dārzeņos. Kopējais organisko skābju saturs selerijas saknēs samazinājās kaltēšanas un pirmapstrādes rezultātā, taču burkānos tas bija main̄̄gs. Askorbīnskābes saturs abos Apiaceae dārzeņos samazinājās pēc visu veidu apstrādes.

6. Mikroviḷnu-vakuuma kaltē kaltētiem dārzeņiem, veicot paraugu apstrādi ar tvaiku, novērots būtisks fenolu, flavonoīdu un fenolskābju pieaugums, 
kā arī attiecīgi augstāka antiradikālā aktivitāte. Kopējais fenolu, flavonoīdu un fenolskābju saturs Apiaceae dārzeņos bija zemāks nekā Apiaceae garšaugos. Pirmapstrāde ar tvaiku un tai sekojoša mikrovilı̣uvakuuma kaltēšana palielināja fenolu saturu, bet samazināja flavonōidu un fenolskābju saturu seleriju saknēs un burkānos. Augstāka antiradikālā aktivitāte ir noteikta mikroviļnu-vakuuma kaltē kaltētos dārzeņos ar tvaika pirmapstrādi, izmantojot gan ABTS, gan DPPH metodi.

7. Galveno komponentu analīze norāda, ka seleriju saknēs galvenie fenolu savienojumi ir katehīns, rutīns, galluskābe, 3.4-dihidroksibenzoskābe, 4hidroksibenzoskābe, sinapīnskābe, 2-hidroksikanēlskābe un 3hidroksikanẹ̄lskābe, bet burkānos - 3.4-dihidroksibenzoskābe, 3.5dihidroksibenzoskābe, sinapīnskābe, katehīns un kaempferols.

8. Izmantojot abas kaltēšanas metodes, Allium garšaugu paraugu beigu mitrums bija zemāks par 10\%. Būtiskas krāsu izmaiņas tika novērotas gan konvencionāli, gan mikrovilı̣u-vakuuma kaltē kaltētos garšaugos.

9. Kopējo karotinoīdu saturu kaltētos Allium garšaugos būtiski ietekmē to pirmapstrāde ar tvaiku - puravos karotinoīdu saturs paaugstinās, bet sīpolos un kiplokos samazinās. Organisko skābju daudzums, tai skaitā askorbīnskābe, izmainījās visu apstrādes metožu rezultātā.

10. Kopējo fenolu saturs minimāli mainījās, izmantojot pirmapstrādi ar tvaiku, bet būtiski palielinājās konvencionāli kaltētos Allium garšaugos. Pretēja sakarība tika novērota kopējo flavonōidu un fenolskābju saturā, kas pēc kaltēšanas procesiem samazinājās. Palielinoties fenolu saturam kaltētos garšaugos, tika noteikta augstāka antiradikālā aktivitāte.

11. Galveno komponentu analīze norāda, ka puravos galvenie fenolu savienojumi ir katehīns, rutīns, luteolīns, galluskābe, 3.4dihidroksibenzoskābe, hlorogēnskābe, sinapīnskābe un 2hidroksibenzoskābe, sīpolos - galluskābe, ferulskābe, rutīns, kvercetīns, bet ķiplokos - katehīns, 4-hidroksibenzoskābe, cerinsskābe, vanilīns, tferulskābe, 3-hidroksikanēḷskābe un kaempferols.

12. Integrētais novērtējums norāda, ka konvekcijas tipa kaltēšana ir piemērotākā kaltēšanas metode sīpoliem, bet mikroviļ̧nu-vakuuma kaltēšana ķiplokiem un seleriju saknēm, lai iegūtu produktu ar augstāko biologisko vērtību. Pirmapstrāde ar tvaiku (1.5 min) un mikroviḷnuvakuuma kaltēšana ir piemērotākā kaltēšanas metode dillēm. Pirmapstrāde ar tvaiku (3.0 min) un mikrovilı̧nu-vakuuma kaltēšana ir piemērotākā metode puraviem, burkāniem, pētersīḷiem un selerijām.

13. Darbā izvirzītā hipotēze ir pierādīta: kaltējot dārzeņus un garšaugus mikroviļnu-vakuuma kaltē ir iespējams tajos maksimāli saglabāt biolog̣iski aktīvos savienojumus 